\title{
Perspectives on ruminant nutrition and metabolism. II. Metabolism in ruminant tissues
}

\author{
E. F. Annison* and W. L. Bryden \\ Department of Animal Science, University of Sydney, Camden, NSW 2570, Australia
}

\begin{abstract}
The discovery of the dominance of short-chain fatty acids as energy sources in the 1940s and 1950s, as discussed in part I of this review (Annison \& Bryden, 1998) led to uncertainties concerning the interrelationships of glucose and acetate in ruminant metabolism. These were resolved in the following decade largely by use of ${ }^{14} \mathrm{C}$-labelled substrates. Although only small amounts of glucose are absorbed in most dietary situations, glucose availability to ruminant tissues as measured by isotope dilution was shown to be substantial, indicating that gluconeogenesis is a major metabolic activity in both fed and fasted states. Studies with ${ }^{14} \mathrm{C}$-labelled glucose and acetate revealed that in contrast to non-ruminants, acetate and not glucose is the major precursor of long-chain fatty acids in ruminant tissues. Interest in the measurement of energy metabolism in livestock grew rapidly from the 1950s. Most laboratories adopted indirect calorimetry and precise measurements of the energy expenditure of ruminants contributed to the development of new feeding systems. More recently, alternative approaches to the measurement of energy expenditure have included the use of NMR spectroscopy, isotope dilution and the application of the Fick principle to measure $\mathrm{O}_{2}$ consumption in the whole animal and in defined tissues. The refinement of the classical arterio-venous difference procedure in the study of mammary gland metabolism in the 1960s, particularly when combined with isotope dilution, encouraged the use of these methods to generate quantitative data on the metabolism of a range of defined tissues. The recent introduction of new methods for the continuous monitoring of both blood flow and blood $\mathrm{O}_{2}$ content has greatly increased the precision and scope of arterio-venous difference measurements. The impact of data produced by these and other quantitative procedures on current knowledge of the metabolism of glucose, short-chain fatty acids and lipids, and on $\mathrm{N}$ metabolism, is outlined. The role of the portal-drained viscera and liver in $\mathrm{N}$ metabolism is discussed in relation to data obtained by the use of multi-catheterized animals. Protein turnover, and the impact of stress (physical, social and disease related) on protein metabolism have been reviewed. The growth of knowledge of mammary gland metabolism and milk synthesis since the first quantitative studies in the 1960s has been charted. Recent findings on the regulation of amino acid uptake and utilization by the mammary gland, and on the control of milk secretion, are of particular interest and importance.
\end{abstract}

Ruminant metabolism: Short-chain fatty acids: Milk: Arterio-venous differences

Abbreviations: AV, arterio-venous; FIL, feedback inhibitor of lactation; ME, metabolizable energy; NEFA, non-esterified fatty acids; PDV, portal-drained viscera; SCFA, short-chain fatty acids.

*Corresponding author: Professor E.F. Annison, fax +61 24655 0693, email lizt@camden.usyd.edu.au 


\section{Introduction}

The crucial observations of Barcroft et al. (1944) that short-chain fatty acids (SCFA) provide much of the energy requirements of ruminants was the stimulus for sustained research in ruminant metabolism, as discussed earlier (Annison \& Bryden, 1998). In succeeding decades ruminant research has focused on the generation of quantitative data in research areas which include: energy metabolism, mainly to underpin the development of improved systems of feed evaluation; the production and utilization of the main energy-yielding nutrients; amino acid supply and utilization, and protein metabolism. Progress in these areas has been facilitated by the refinement of arterio-venous (AV) difference procedures for the study of metabolism in defined tissues, and by the use of isotopically labelled substrates.

Studies on the metabolism of defined ruminant tissues in recent decades have relied heavily on AV difference studies. The first use of this technique has been attributed to M. A. Chauveau, who in 1887 measured $\mathrm{AV}$ differences of $\mathrm{O}_{2}, \mathrm{CO}_{2}$ and glucose across the levator muscle of the upper lip of the horse (see Zierler, 1976). Zierler (1976) has suggested that this was almost certainly the first application of the principle enunciated by A. Fick in 1870 which implied that net substrate uptake or release may be measured as the product of AV difference and blood flow. The AV difference procedure was little used, however, until the development in the 1950s of reliable methods for the measurement of blood flow. These were brilliantly exploited by J. L. Linzell in his studies on the lactating goat mammary gland from the mid 1950s as discussed later. The success achieved by these studies encouraged the application of the AV difference technique to other major organs and tissues, as outlined in this review.

The use of isotopes in metabolic studies began in the 1930s when Schoenheimer \& Rittenberg (1935) used deuterium-labelled substrates to investigate fat metabolism in mice. The complexity, high cost and relative insensitivity of detection and analysis of stable isotopes restricted the use of isotopes until the advent of radioactive isotopes in the 1950s. The availability of metabolites labelled with ${ }^{14} \mathrm{C}$ and ${ }^{3} \mathrm{H}$, which are easily assayed by relatively simple and inexpensive equipment, was largely responsible for the vast increase in knowledge of the metabolism of ruminant tissues in the 1960s and 1970s (see Annison \& Leng, 1991). Isotopically labelled substrates were used to delineate key metabolic pathways, exemplified by the elucidation of the relative importance of glucose and acetate in lipogenesis and to measure the supply to tissues and rates of oxidation of the major energy yielding nutrients (Annison \& Leng, 1991). The combined use of isotope dilution and AV difference measurements, first introduced in the 1960s has contributed greatly to current knowledge of mammary gland metabolism and may be applied to any tissue with defined venous drainage.

The lactating ruminant has proved invaluable as a research tool in many aspects of ruminant metabolism. Current concepts of the regulation of nutrient partitioning through homeostatic and homeorhetic controls (see Bauman, 1984; Vernon, 1998) owe much to studies on the marked changes in food intake, and on the tissue mobilization and deposition that occur during lactation. Also, the economic and social importance of milk has ensured sustained research on all aspects of milk synthesis and secretion.

An important recent development has been the recognition of the adverse effects of stress (social, environmental, nutritional or disease induced) on the efficiency of protein deposition in livestock. It is indeed fortunate that changes to the management of livestock to minimize stress are consistent with both the recommendations of animal welfare groups and increased efficiency of production.

This review reflects the research interests of the authors, who acknowledge that constraints of space have precluded consideration of many valuable contributions to ruminant metabolism. 


\section{Energy metabolism}

There were few quantitative calorimetric studies before the Second World War, but interest in the measurement of energy metabolism in livestock grew rapidly in Europe and USA in the immediate post-war period (van Es, 1994). The first requirement was reliable methodology, and as discussed by van Es (1994), most laboratories adopted indirect calorimetry (Blaxter, 1962; McClean \& Tobin, 1987). Within a decade or so, enough data on the energy expenditure of ruminants over a range of nutritional and physiological states had been accumulated for Blaxter (1962) to propose the development of a new system of feed evaluation, the metabolizable energy (ME) system. This system, adopted by the Agricultural and Food Research Council in the UK has been substantially modified and improved since its inception (see Agricultural and Food Research Council Technical Committee on Responses to Nutrients, 1990). From the immediate post-Second World War period until his death, Sir Kenneth Blaxter's contributions to current understanding of the energy metabolism of livestock were immense, and well documented in his two books on this subject (Blaxter, 1962, 1989). At the time that Blaxter and his colleagues, who included D. G. Armstrong, a notable contributor to energy metabolism in his own right, were developing the ME system, K. Nehring and R. Schiemann and their colleagues in East Germany were using their own calorimetric data to improve the net energy system (Nehring et al. 1969; Schiemann, 1969). In fact, calorimetric data were subsequently used by many countries to develop their own systems for evaluating the energy requirements of livestock, e.g. Netherlands (van Es, 1978) and France (Vermorel, 1978). All of these systems of feed evaluation, however, including the ME system, are handicapped by lack of information on the nature of the energy yielding nutrients which become available to the tissues, and on the efficiency with which these nutrients are used for productive purposes. R. A. Leng, for example, has highlighted the inadequacies of the ME system when animals are fed on highfibre diets supplemented with small amounts of rumen non-degradable protein (Leng, 1990).

A. J. F. Webster has perceptively discussed both the strengths and weaknesses of the measurement of energy exchanges in the whole animal (Webster, 1989). The main strength of the approach is the accurate measurement of energy expenditure, and the weaknesses are those which afflict the ME system. Other issues are that calorimetry is non-invasive but requires the confinement of experimental animals, which usually restricts physical activity.

A major development in non-invasive procedures arose from the demonstration by Williams \& Gadian (1986) that NMR spectroscopy could be used to measure metabolic processes in small laboratory animals. At this time the high cost of the equipment and size constraints have restricted the use of NMR to measure energy expenditure in livestock, but larger magnetic systems are becoming available (Scollan, 1994).

The use of invasive procedures is acceptable only when essential data cannot be obtained in any other way. Two procedures in this category, which are discussed later, are the use of isotope dilution to measure $\mathrm{CO}_{2}$-production rates and the Fick principle to measure $\mathrm{O}_{2}$ consumption in the whole animal.

\section{Measurement of energy expenditure by isotope dilution}

Use of ${ }^{14} \mathrm{C}$ - and ${ }^{13} \mathrm{C}$-labelled carbon dioxide. Procedures based on the single injection (White $\&$ Leng, 1969) or continuous infusion (Corbett et al. 1971) of ${ }^{14} \mathrm{C}$-labelled $\mathrm{NaHCO}_{3}$ are equally effective, but the former method requires the multiple sampling of body fluids. In the continuous infusion procedure, the objective is to achieve constancy of specific radioactivity of ${ }^{14} \mathrm{CO}_{2}$ in the blood, and for this reason, the infusion is continued for up to $12 \mathrm{~h}$ (Whitelaw et al. 
1972). The intrinsic problem with the method is that the $\mathrm{CO}_{2}$ pool is not homogenous, but consists of many interlinked pools of varying turnover rate, and even after $12 \mathrm{~h}$ the specific radioactivity of ${ }^{14} \mathrm{CO}_{2}$ in expired air and in body fluids continues to rise slowly.

Rocha et al. (1994) have measured $\mathrm{CO}_{2}$ entry rates in sheep by the continuous infusion of $\mathrm{NaHCO}_{3}$ labelled with the stable isotope ${ }^{13} \mathrm{C}$. Experiments in which $\mathrm{CO}_{2}$ entry-rates were measured in sheep placed in open-circuit respiration hoods to measure $\mathrm{CO}_{2}$-production rates directly showed that $\mathrm{CO}_{2}$ entry-rates were considerably higher (20-37\%) than direct measurements of $\mathrm{CO}_{2}$ production. The differences in values were shown to be largely due to the sequestration of labelled C in tissues (Rocha et al. 1994). These experimental data indicate that $\mathrm{CO}_{2}$ entry-rates uncorrected for sequestration of labelled $\mathrm{C}$ may grossly overestimate calculated values for energy expenditure. Further, they confirm earlier views that comparison of the specific radioactivities of circulating ${ }^{14} \mathrm{C}$-labelled metabolites and arterial-blood ${ }^{14} \mathrm{CO}_{2}$ at the concluding stages of continuous infusion experiments may underestimate the contribution of the metabolite to total oxidative metabolism (Annison, 1964; Annison et al. 1967a).

Doubly-labelled water. Doubly-labelled water may also be used to measure energy expenditure from whole-body $\mathrm{CO}_{2}$ production. The basis of this method is that whereas $\mathrm{H}$ is lost from the body mainly as water, $\mathrm{O}_{2}$ is lost both in water and as $\mathrm{CO}_{2}$ (Lifson et al. 1955). This implies that if the animal is given a dose of water enriched with ${ }^{2} \mathrm{H}_{2}{ }^{18} \mathrm{O}$ to label the total water pool, the degree of enrichment (specific activity) of ${ }^{18} \mathrm{O}$ will decline faster than that of deuterium and allow $\mathrm{CO}_{2}$ production to be calculated.

The doubly-labelled water method has been compared with indirect calorimetry in studies with adult man (Seale et al. 1989). The authors observed reasonable agreement between energy expenditure determined using doubly-labelled water and that calculated from ME intake. These values, however, were much higher than those obtained by calorimetry. These differences were attributed to the higher levels of activity of the subjects when not physically restrained by the requirements of calorimetry. Estimates of energy expenditure obtained in quail by the doublylabelled water procedure were also higher than those determined simultaneously by indirect calorimetry, but no single cause was identified which could account for the differences in those values (Ward \& MacLeod, 1991).

\section{Measurement of $\mathrm{O}_{2}$ consumption across lungs and defined tissues}

A new procedure for the measurement of energy expenditure by the direct measurement of $\mathrm{O}_{2}$ consumption by the whole animal was outlined by Giles et al. (1995). $\mathrm{O}_{2}$ consumption in sheep was measured continuously by monitoring cardiac output, and the changes in $\mathrm{O}_{2}$ concentration across the lungs (Fick principle). Key features of the method are the continuous measurement of blood flow through the pulmonary artery by ultrasound, and of changes in blood $\mathrm{O}_{2}$ concentration by fibre-optic oximetry (Giles et al. 1995). The method has been used to measure energy expenditure in exercising sheep (Shahneh et al. 1994).

The major disadvantage of the new procedure is that it is invasive. Major surgery is involved in placing the blood-flow cuffs around the pulmonary artery. Recovery from surgery is usually complete after about $5 \mathrm{~d}$, when food intake returns to the pre-surgery level. Other disadvantages are the need to restrain animals to maintain the patency of catheters which remain usable for several weeks. The procedure measures only $\mathrm{O}_{2}$ consumption, and the precision of the method would be improved if $\mathrm{CO}_{2}$ production could also be monitored to provide a continuous record of RQ. 
The advantages of the method are that the animal can feed normally, and that $\mathrm{O}_{2}$ consumption is measured continuously. The procedure relies heavily on transit-time ultrasound to measure blood flow continuously, and as discussed elsewhere, this new approach to the measurement of blood flow is proving invaluable in AV difference studies in defined organs and tissues.

The need to generate data on defined tissues in order to interpret the patterns of energy expenditure of ruminants maintained on different diets was stressed by Lobley (1991). In his evaluation of the application of AV difference procedures to the liver and portal-drained viscera (PDV), Lobley (1991) highlighted the intrinsic problems stemming from the complex vasculature of the liver and the heterogeneity of visceral tissues. This situation is in marked contrast to the mammary gland, where the accessibility of the gland, simple vasculature and relative homogeneity of mammary tissue has facilitated the application of AV difference techniques to elucidate the main features of mammary metabolism and milk synthesis, as discussed elsewhere (p. 163).

\section{Glucose metabolism}

The central role of glucose in mammalian metabolism had been recognized early in the 19th century. Indeed, the prolonged controversy concerning the role of circulating glucose in lactose synthesis began mid-19th century (see Mepham, 1993). The prevailing view before the discovery of the ruminal production and absorption of SCFA (Barcroft et al. 1944) was that absorbed glucose was the major dietary energy source in ruminants, as in non-ruminants.

\section{Glucose-acetate interrelationships}

Although the quantitative importance of acetate as an energy source for ruminants had been established by the late 1940s, little was known of the pathways of utilization of acetate, or of glucose. In particular, the relative importance of these substrates in lipogenesis was largely unknown. Crucial data on their roles in long-chain fatty acid synthesis were generated by S. J. Folley and his colleagues in studies in which acetate and glucose, singly or in mixture, were incubated with mammary gland slices from lactating rats or sheep. These studies, which made use of newly available isotopically labelled $\left[{ }^{13} \mathrm{C}\right]$ acetate and $\left[{ }^{14} \mathrm{C}\right]$ glucose, revealed that whereas glucose accounted for $62 \%$ of fatty acid synthesis in rat mammary tissue, the corresponding value for sheep tissue was only $3 \%$ (Balmain et al. 1954). The small contribution of glucose to fatty acid synthesis in ruminant mammary tissue was shown later to apply to all ruminant tissues by Ballard et al. (1969) in their seminal studies on gluconeogenesis and lipogenesis. This striking difference in the role of glucose and acetate in lipogenesis was shown to stem from the very low levels of ATP-citrate lyase (EC 4.1.3.8) activity in ruminant tissues (Ballard et al. 1969).

The limited contribution of glucose to lipogenesis lent support to the view in the late 1950s that glucose metabolism was of minor importance in ruminants. Other factors contributing to this view were the paucity of alimentary glucose, since on most diets few $\alpha$-linked glucose polymers reach the small intestine (Heald, 1952; Lindsay, 1970), and the relative insensitivity of sheep to the hypoglycaemic action of insulin (Reid, 1952). The crucial role of glucose in ruminant metabolism was first recognized by D. B. Lindsay, who concluded from limited data that glucose requirements in ruminants are similar in magnitude to those of non-ruminants and that gluconeogenesis is a major metabolic activity in both fed and fasted states (Lindsay, 1959). 
Evidence of the quantitative importance of glucose in ruminant metabolism was not obtained until the early 1960s, when isotope dilution studies using $\left[{ }^{14} \mathrm{C}\right]$ glucose revealed that glucose production rates in ruminants were comparable to those of fasting non-ruminants (Annison \& White, 1961; Ballard et al. 1969). Similar studies based on the use of ${ }^{14} \mathrm{C}$-labelled acetate demonstrated the relatively high contribution of acetate to total oxidative metabolism in sheep (Annison \& Lindsay, 1961). In the following decade glucose was shown to be essential for milk synthesis and as an energy source for the brain, pregnant uterus and for the generation of reducing equivalents for lipogenesis (see Ballard et al. 1969; Annison, 1983).

Isotope dilution studies in ruminants proliferated in the $1960 \mathrm{~s}$, and ${ }^{14} \mathrm{C}$-labelled substrates were used to measure the availability and rates of oxidation of the major energy yielding nutrients (acetate, glucose, 3-hydroxybutyrate and plasma non-esterified fatty acids (NEFA)) in the whole animal (Annison et al. 1967a) and in organs and defined tissues (see Linzell \& Annison, 1975; Annison, 1991).

In probably the first reported studies in which isotope dilution and AV difference procedures were combined to examine defined ruminant tissues, Annison et al. (1963) measured the uptake and oxidation of glucose and acetate by the testis and epididymis of the ram. The same procedure subsequently proved invaluable in the study of mammary gland metabolism.

\section{Gluconeogenesis}

The major precursors of glucose in ruminants are propionate and glucogenic amino acids, as predicted by Lindsay (1959). Confirmation was provided by isotope studies with ${ }^{14} \mathrm{C}$-labelled substrates. Lindsay (1978), taking into account the crossover of radioactivity during movement of $\mathrm{C}$ through the Krebs cycle, observed that 41, 20 and $4 \%$ of glucose production in sheep fed to maintenance was derived from propionate, lactate and glycerol respectively, the balance (approximately $35 \%$ ) coming from amino acids. Other studies estimated the contribution of glucogenic amino acids to range from 12-30\% (Wolff \& Bergman, 1972; Bergman, 1973). Clearly these proportions will vary with the quantity and quality of food consumed and the physiological status of the animal. The striking differences between responses to plane of nutrition in growing, mature, pregnant and lactating ruminants have long been recognized.

Considerable progress in defining the contributions of glucogenic substrates to gluconeogenesis has been made using animals surgically prepared with portal- and hepatic-venous catheters (see Reynolds, 1995). The preparation of these animals involves time-consuming and expensive surgery and aftercare. The latter includes, for example, maintenance of catheter patency, avoidance of infection and management practices that encourage the return to presurgery feed intakes as soon as possible. Restoration of normal feeding is, in fact, an essential prerequisite for animals used in quantitative metabolic studies. These exacting experimental and logistical requirements inevitably limit the number of animals available for experimentation, and data are rarely generated over a range of nutritional and physiological states.

Studies with mature cattle prepared with portal- and hepatic-venous catheters and fed near maintenance showed that glucogenic amino acids contributed to $33-49 \%$ of glucose production by the liver (Maltby et al. 1993; Reynolds et al. 1994). In the same studies the net removal of propionate, glucogenic amino acids and L-lactate accounted for $98-118 \%$ of hepatic glucose release. In earlier studies using the same techniques, Reynolds et al. (1988) showed that in lactating dairy cows fed ad libitum, propionate could account for as much as $55 \%$ of hepatic glucose output, with smaller contributions from L-lactate $(17 \%)$ and amino acids (16\%). In isotope dilution studies, Steinhour \& Bauman (1988) measured the contribution 
of $\left[{ }^{14} \mathrm{C}\right]$ propionate to glucose production in mature sheep fed at maintenance using a procedure that corrected for the crossover of radioactivity in the Krebs cycle. They reported that $95 \%$ of absorbed propionate was converted to glucose, which accounted for $78 \%$ of glucose production. Although the actual contribution of propionate to gluconeogenesis will vary with nutritional and physiological status, earlier views that propionate is the major precursor of glucose in fed ruminants have been confirmed.

Lactate is not a major precursor of glucose in fed cattle, but assumes a major role during feed restriction (Lomax \& Baird, 1983). In reviewing the available data, Reynolds (1995) concluded that in lactating cows L-lactate may contribute significantly to gluconeogenesis, but that in growing animals in positive energy balance, L-lactate may be released by the liver.

Net appearance of L-lactate across the PDV is determined primarily by ME intake (see Reynolds, 1995). The nature of the response appears to depend on the proportions of propionate and butyrate absorbed, which in turn influences the NAD : NADH ratio in the liver (Reynolds, 1995).

Reynolds and his colleagues have conducted a range of studies on the exchange of nutrients across the PDV and liver (see Reynolds, 1995), and their data showed that the rate of glucose production by the liver accounted for $42 \%$ of the energy of the substrates released. Danfaer (1994) reported a positive relationship between $\mathrm{O}_{2}$ consumption and glucose production, but both indices of metabolism are highly correlated with ME intake.

Exercise has a marked effect on gluconeogenesis in sheep (Pethick et al. 1991). At moderate exercise, euglycaemia is maintained despite up to a 2-fold increase in glucose entry rate, but as the rate of exercise increases, glucose production by the liver and the level of hyperglycaemia increase considerably (Pethick et al. 1991). These responses to exercise suggest that normal feedback control of hepatic glucose production is maintained until, at high work rates, a sympathoadrenal response results in increased glucose product independent of normal feedback signals (Pethick et al. 1991). An interesting finding in later studies was that NEFA are partly oxidized to acetate during sustained exercise, a mechanism which might operate in other species (Pethick, 1993).

The effects of raised circulating levels of glucose on gluconeogenesis was first examined in sheep in which an intravenously infused glucose load was shown to completely block or greatly reduce gluconeogenesis (Annison \& White, 1961). The blood glucose levels in these animals were high and unphysiological, but studies with normally fed sheep absorbing relatively large amounts of glucose have also demonstrated partial inhibition of endogenous glucose production (Janes et al. 1985). Net and total small intestinal absorption of glucose were measured in sheep fed on either dried grass or ground maize. In addition, whole-body glucose entry was measured by isotope dilution. As expected, intestinal absorption of glucose was low on the dried-grass diet, but high on the ground-maize diet, and in the latter animals, endogenous glucose production was partially suppressed, as discussed by Weekes (1991).

The situation in cattle is apparently quite different, since it has been reported that on a range of diets, including ground maize, glucose absorption is always low (Huntington \& Reynolds, 1986; see Weekes, 1991). These data indicate extensive visceral utilization of absorbed glucose in cattle, but the metabolic fate of absorbed glucose has not been delineated.

\section{Intestinal starch digestion}

Starch hydrolysis in the small intestine of ruminants is achieved by the action of $\alpha$-amylase assisted by surface oligosaccharidases, as in other species (Gray, 1992; Harmon, 1993). Since 
on average 5-20\% of starch consumed by cattle is digested post-ruminally (Huntington, 1997), the extent of digestion in the small intestine affects the efficiency of feed utilization. The assimilation of starch as glucose is energetically more efficient than fermentation to SCFA in the rumen or lower gut (Preston \& Leng, 1987), and Owens et al. (1986) in a review of production data from cattle fed on maize- or sorghum-based diets, concluded that starch digested in the small intestine provided $42 \%$ more energy than starch digested in the rumen.

Starch reaching the small intestine is usually not fully digested. Data reported in the reviews of Harmon (1992) and Owens et al. (1986) and analysed by Huntington (1997) indicated that about $55 \%$ of maize starch reaching the small intestine is digested, and that incomplete digestion is due to lack of $\alpha$-amylase. Harmon (1993) cited evidence that the supply of starch-digesting enzymes was related more closely to total dietary energy intakes than to starch intakes. The reported increase in starch digestibility in the small intestine of sheep and steers in response to increased protein supply to the small intestine (Taniguchi et al. 1993, 1995) is consistent with this finding and with the established view that the secretion of all digestive enzymes responds to increased protein supply.

Huntington (1997) has questioned the generally accepted view that the displacement of starch digestion from the rumen to the small intestine increases the efficiency of ruminant production. Apart from the energy gained by the direct hydrolysis of starch to glucose, the escape of starch from the rumen reduces the pressure on $\mathrm{pH}$ stability stemming from SCFA, and possibly lactic acid production. The more important issue, however, is the impact of site of digestion on the supply of amino acids to the small intestine. Microbial-protein synthesis in the rumen, which is dependent on the energy supplied by fermentation, will inevitably decline in response to the escape of dietary starch from the rumen. This reduction in microbial-protein synthesis will reduce the efficiency of feed utilization only if the flow of available amino acids to the small intestine from all sources, including undegraded dietary protein, fails to meet the amino acid requirements of the animal. The high overall digestibility of starch implies that the fraction which escapes digestion in the small intestine is fermented to SCFA in the lower gut, which are readily absorbed and utilized, but the microbial protein produced in this process is lost to the host animal.

\section{Intestinal transport of glucose}

In pre-ruminants, the active absorption of D-glucose and D-galactose is made possible by high levels of the D-glucose transporter SGLTI in the luminal membrane of enterocytes driven by an electrochemical gradient maintained by $\mathrm{Na}^{+}, \mathrm{K}^{+}$-ATPase (EC 3.6.1.37) located on the basolateral membrane (Shirazi-Beechey et al. 1995). At weaning there is a massive decline (100-500-fold) in the activity and abundance of SGLTI, and a corresponding fall in the capacity of the small intestine to absorb monosaccharides. This process is closely related to the milk content of the diet, since prolonging the period of milk-feeding in lambs retards the loss of $\mathrm{Na}^{+}$-dependent monosaccharide transport (see Shirazi-Beechey et al. 1995).

The greatly reduced capacity to absorb monosaccharides at weaning can be reversed in ruminant sheep by infusing D-glucose or methyl- $\alpha$-D-glucopyranoside $(30 \mathrm{mM})$ into the duodenum, when rates of $\mathrm{Na}^{+}$-dependent $\mathrm{D}$-glucose transport rise to pre-ruminant levels. Kinetic studies have shown that the induced transporter is identical to that normally present (LescaleMatys et al. 1993; Shirazi-Beechey et al. 1995). This ability of the small intestine in mature ruminants to adapt rapidly to the inflow of monosaccharides suggests that incomplete starch 
digestion in the small intestine usually reflects inadequate amylolytic activity, and not capacity to absorb glucose.

\section{Role of glucose in lipogenesis}

Glucose is recognized as the major source of glycerol used in triacylglycerol synthesis, and glucose oxidation provides much of the energy required for fatty acid synthesis (Vernon, 1981). As discussed earlier (pp. 151-152), low levels of ATP-citrate lyase in adipose tissue and mammary tissue, the main sites of lipogenesis in ruminants, explain the minor contribution of glucose to fatty acid synthesis. Some incorporation of glucose $\mathrm{C}$ into fatty acids, via lactate, has been reported (Prior, 1978).

Ballard et al. (1972) showed that sheep adipose tissue adapts to the continuous supply of exogenous glucose for some weeks by increased levels of ATP-citrate lyase. In recent studies, Rowe \& Pethick (1994) reported that the effectiveness of a range of cereal grains in raising ATP-citrate lyase activity in adipose tissue when fed to sheep for 6 weeks was highly correlated with the amounts of starch reaching and undergoing digestion in the small intestine. The absorption of large amounts of glucose in sheep fed on maize was reported by Janes $e t$ al. (1985). In contrast, in cattle fed on grain, there is little absorption of glucose (Reynolds et al. 1988), suggesting that under normal feeding conditions, the contribution of glucose to fatty acid synthesis is low.

\section{Short-chain fatty acid metabolism}

Acetic, propionic and butyric acids were first detected in rumen contents in the 19th century (see Hungate, 1966) but their nutritional importance was not recognized until the classical studies of J. Barcroft and his colleagues discussed earlier. These studies were made possible by somewhat cumbersome analytical procedures based on liquid-gel partition chromatography (Elsden, 1946). The application of new, rapid and accurate GLC procedures to SCFA analysis (James \& Martin, 1952) revealed that in addition to acetate, propionate and butyrate, small amounts of isobutyric, isovaleric and 2-methylbutyric acids derived from valine, leucine and isoleucine, and of $n$-valeric acid, were also present in the rumen (Annison, 1954). The branched-chain SCFA were subsequently shown to be essential growth factors for some cellulolytic bacteria in the rumen (Bryant \& Robinson, 1962). The production of SCFA in the gastrointestinal tract in various species was reviewed by E. N. Bergman shortly before his untimely death in 1989 (Bergman, 1990).

Rittenberg \& Bloch (1945) showed that acetate is a major precursor of fatty acids in mammalian tissues before the importance of acetate as an energy source in ruminants had been established (Elsden \& Phillipson, 1948). The utilization of acetate by sheep tissue was demonstrated by Reid (1950), and McClymont (1951) reported substantial uptake of acetate by the mammary gland of the lactating cow. These studies preceded the advent of GLC procedures for SCFA analysis, which were later used to reveal the presence of small amounts of propionate and butyrate, and somewhat surprisingly, formate in ruminant blood (Annison, 1954). The source of blood formate, shown to have a significant entry rate in sheep (Annison \& White, 1962a) has not been identified (see Lindsay, 1993a).

Even after prolonged starvation, or after the removal of rumen contents, the level of acetate in ruminant blood remains at about $0.3 \mathrm{mmol} / \mathrm{l}$, which is similar to the concentration of acetate in the blood of non-herbivores (Annison, 1954). This suggested the production of considerable 
amounts of endogenous acetate, a finding confirmed by isotope dilution studies which showed that in sheep about $25 \%$ of total acetate turnover is of non-alimentary origin (Annison \& White, 1962b; Bergman \& Wolff, 1971; Costa et al. 1976).

\section{Utilization of short-chain fatty acids by the portal-drained viscera}

The finding by Masson \& Phillipson (1951) that the proportion of butyrate in portal-blood SCFA was much lower than in ruminal SCFA prompted the pioneering studies of R. J. Pennington and his colleagues on the metabolism of SCFA by rumen epithelium in vitro (Pennington, 1952, 1954; Annison \& Pennington, 1954; Pennington \& Sutherland, 1956). Butyrate and propionate were shown to be extensively metabolized, but acetate, $n$-valerate and the branched-chain SCFA were all utilized to some extent by rumen epithelium.

The studies of Masson \& Phillipson (1951) based on the analysis of portal blood were extended by Annison et al. (1957) using an improved portal-vein catheterization procedure devised by K. J. Hill (Lewis et al. 1957) and GLC for SCFA analysis. The extensive conversion of butyrate to ketone bodies and the uptake of considerable amounts of SCFA was confirmed by portal-arterial difference measurements, but quantitative data on the inflow of SCFA into the portal system could not be obtained in the absence of data on portal blood-flow (Annison et al. 1957). This problem was overcome by E. N. Bergman and his colleagues, who developed the necessary multi-catheterized animal preparations and dye dilution procedures for the measurement of portal blood-flow (Bergman, 1975). The first quantitative studies on SCFA metabolism by the liver and PDV which used these procedures (Bergman \& Wolff, 1971) revealed the apparent utilization of considerable amounts of SCFA by the PDV. This topic was reviewed by Seal \& Reynolds (1993), who concluded that $30-60 \%$ of acetate, $20-70 \%$ of propionate and $30-90 \%$ of butyrate produced in or infused into the rumen cannot be accounted for in portal blood.

In recent studies Kristensen et al. (1996) have examined the portal recovery of intraruminally infused SCFA in sheep fitted with ultrasonic blood-flow probes. These studies showed that SCFA and 3-hydroxybutyrate accounted for $55 \%$ of absorbed energy but no data were obtained on the products of SCFA metabolism by the PDV, the most important of which are lactate and D-3-hydroxybutyrate. The failure to account for possible metabolites of propionate and butyrate, however, is of minor importance quantitatively when compared with acetate, which is the major contributor to the energy loss associated with SCFA absorption. The comprehensive data on acetate metabolism reported by Kristensen et al. (1996) were entirely consistent with literature values for the portal recovery of acetate (see Seal \& Reynolds, 1993). All of the available data indicate that the measured portal recovery of acetate is, at most, $70 \%$.

\section{Efficiency of utilization of acetate}

Early calorimetric studies by D. G. Armstrong and colleagues (Armstrong \& Blaxter, 1957; Armstrong et al. 1957, 1961) based on the administration of acetate to sheep fed on high-fibre diets demonstrated that acetate is utilized with a relatively low efficiency for body tissue synthesis. In contrast, subsequent studies by E. R. Ørskov and colleagues (see Ørskov, 1990; Ørskov \& MacLeod, 1993), showed that acetate is used as efficiently as propionate and butyrate.

Direct calorimetric experiments confirmed the low efficiency of utilization of acetate in cattle fed on lucerne (Medicago sativa) hay only, but when the diet contained $570 \mathrm{~g}$ maize $/ \mathrm{kg}$, 
the efficiency of acetate utilization rose from $27 \%$ to $69 \%$ (Tyrrell et al. 1979). Although no information on ruminal SCFA concentrations were presented in this study, it is almost certain that the acetate: propionate ratio would have been much higher in the hay-fed cattle than in those fed on the maize-rich diet (see Annison \& Armstrong, 1970). The significance of the data of Tyrrell et al. (1979) lies in the high precision of the well-established calorimetric procedures employed. We may speculate that had Tyrrell and his colleagues had the resources to conduct a dose-response study based on feeding varying proportions of hay and maize, and supported by flux rate and metabolic data on glucose and acetate, much of the succeeding controversy on the efficiency of acetate utilization would have been avoided.

Armstrong (1965) first suggested that an inadequate supply of reduced NADP may limit the conversion of acetate to long-chain fatty acids. The crucial role of glucose, derived from propionate and glucogenic amino acids, in the provision of reducing equivalents and as the source of glycerol-3-phosphate in lipogenesis was subsequently recognized by a number of investigators (Gill et al. 1984; Black et al. 1987).

Ørskov (1990) and Ørskov \& MacLeod (1993) suggested that differences in heat production observed between diets are not related to ruminal SCFA proportions. Blaxter (1989) has pointed out, however, that in many of their feeding experiments with acetate, and in studies based on the intragastric infusion of SCFA, the casein component of the diet or infusate would inevitably constitute a source of glucogenic amino acids, and provide sufficient reducing equivalents via glucose to account for the relatively high efficiency of acetate utilization.

Evidence that high-fibre diets which result in high proportions of ruminal acetate are utilized less efficiently than diets which produce more ruminal propionate was obtained in the comprehensive calorimetric studies of W. P. Flatt and his colleagues on the efficiency of milk synthesis in high-yielding cows (see Annison \& Armstrong, 1970). In studies with mixed diets containing different levels of lucerne, the efficiency of utilization of ME for milk synthesis declined with diets containing more than $750 \mathrm{~g}$ lucerne $/ \mathrm{kg}$. The molar proportion of acetate in ruminal SCFA rose to about $70 \%$ at this high level of lucerne feeding. These findings support the view that the lower efficiency of utilization of energy in animals fed on high-fibre diets is due to the inadequate supply of glucogenic substrates which results in a critical shortage of reducing equivalents for the efficient use of acetate and other non-glucogenic substrates.

\section{Nitrogen metabolism}

The extensive research in the 1950s and 1960s which revealed the key features of $\mathrm{N}$ metabolism in the rumen tacitly assumed that the post-ruminal digestion of protein, be it of microbial or dietary origin, would be similar to that known to occur in non-ruminants. Furthermore, the metabolism of amino acids in ruminant tissues was assumed to be qualitatively similar to that of non-ruminants. Subsequent studies have largely confirmed these assumptions.

\section{Nitrogen metabolism of the portal-drained viscera and liver}

Quantitative studies of the uptake and oxidation, and release of substrates has been made possible by the multi-catheterization of the major blood vessels of the viscera and liver, as described by Lindsay (1993b). Simultaneous production and utilization of metabolites can be measured by the use of labelled substrates using AV difference, or portal-arterial difference procedures developed from the pioneering studies of J. L. Linzell and E. N. Bergman, and their 
colleagues (see Bergman, 1975; Linzell \& Annison, 1975). The precision of current procedures has been much improved by the replacement of dye-dilution procedures for the measurement of blood flow with the ultrasonic method, which monitors blood flow continuously. Nevertheless, the cautionary comments of Lindsay (1993b) concerning precision still apply, particularly when substrate uptake or release is small relative to the accuracy of the analytical procedures, as with amino acids.

Portal drained viscera. Tagari \& Bergman (1978) reported that in sheep, less than $50 \%$ of most amino acids disappearing from the small intestine could be accounted for in portal blood. Similar results have been reported in subsequent studies with sheep and cattle (see Lindsay, $1993 b$ ). This uptake of amino acids by the gut was accounted for by the synthesis of secretory proteins, the replacement of epithelial cells and the metabolism of certain amino acids (see Lindsay, 1993b). In addition, some amino acids may be absorbed as peptides (Webb, 1990), although recent studies based on the use of labelled phenylalanine in multi-catheterized lambs (Neutze et al. 1996) showed that amino acids were absorbed from the small intestine as free amino acids.

Isotope dilution studies have demonstrated high rates of protein synthesis in the PDV of ruminants (see Lindsay, 1993b). The gut, in fact, accounts for 25-30\% of whole-body protein synthesis (Harris et al. 1990) and the small intestine exhibits a particularly high rate of protein synthesis (Ahaix \& Arnal, 1987). van der Walt (1993) has comprehensively reviewed N metabolism in the rumen, small intestine, large intestine and liver.

Liver. van der Walt (1993) and Reynolds (1995) in their outstanding reviews of liver metabolism in ruminants have emphasized that information on rates of nutrient absorption and metabolism by the liver of unanaesthetized fed animals is best obtained by the multi-catheterization procedures discussed earlier. The liver removes and converts to urea virtually all of the $\mathrm{NH}_{3}$ produced in the rumen and lower gut and absorbed into the portal system. Part of this $\mathrm{NH}_{3}$ originates from urea returned to the alimentary tract via blood and saliva (Huntington, 1989; van der Walt, 1993). There is a high correlation between $\mathrm{N}$ intake and net PDV absorption of $\mathrm{NH}_{3}$ and not surprisingly, there is a similar relationship between digested $\mathrm{N}$ and net PDV $\mathrm{NH}_{3}$ absorption (see Reynolds, 1995). In a series of studies, net PDV absorption of $\mathrm{NH}_{3}$ represented approximately $49 \%$ of $\mathrm{N}$ intake, and approximately $70 \%$ of digested $\mathrm{N}$ (Reynolds et al. 1992a).

The net PDV absorption of $\alpha$-amino-N is determined more by ME intake than $\mathrm{N}$ intake or digested $\mathrm{N}$, reflecting the relationship between organic matter digestion and microbial-protein synthesis in the rumen (see Reynolds, 1995). In cattle, $\alpha$-amino- $N$ absorption across PDV was approximately $33 \%$ of $\mathrm{N}$ intake and approximately $48 \%$ of digested $\mathrm{N}$, although $\alpha$-amino-N underestimates total amino acid levels (see Reynolds, 1995).

The available information on the removal of individual amino acids by the liver has been summarized by Reynolds (1995). Uptakes of non-essential amino acids usually exceed those of essential amino acids; in mature cattle extraction rates $(\mathrm{A}-\mathrm{V} / \mathrm{A} \times 100$, where $\mathrm{A}$ is the arterial concentration and $\mathrm{V}$ is the venous concentration) for non-essential and essential amino acids of $8-11 \%$ and 4-7\% respectively have been reported (Maltby et al. 1993).

Reynolds (1995), in illustrating the responsiveness of the liver to amino acid supply, has drawn attention to the study of Guerino et al. (1991), in which beef steers were infused abomasally with casein for $3 \mathrm{~d}$. Increased net PDV amino-N absorption was matched equally by increased removal by the liver, and the release of amino acids to peripheral tissues was unchanged. Similarly, in growing cattle treated with growth hormone, the catabolism of amino acids in the liver was reduced in response to increased body requirements for protein synthesis (Reynolds et al. 1992b). The role of the liver in ureagenesis and recycling of $\mathrm{N}$ has been extensively discussed by van der Walt (1993). 
An intriguing aspect of the integration of amino acid and $\mathrm{NH}_{3}$ metabolism by the liver has been revealed by the studies of Lobley et al. (1995) in which increases in liver urea production in response to the infusion of $\mathrm{NH}_{3}$ into the portal system were twice the rate of $\mathrm{NH}_{3}$ removal by the liver. This finding is consistent with the accepted involvement of amino acids, and particularly aspartate, in urea formation. In further studies, Lobley et al. (1995) showed that when

${ }^{15} \mathrm{NH}_{3}$ was supplied to the liver, $97 \%$ of the labelled urea produced was singly labelled. The quantitative significance of this amino acid demand to support urea synthesis when $\mathrm{NH}_{3}$ inflows are sustained at relatively high levels has been discussed by Lean \& Westwood (1997). Highyielding dairy cows grazed on lush pastures of high protein and non-protein $\mathrm{N}$ content often exhibit raised $\mathrm{NH}_{3}$ levels, which result in high rates of urea production. In addition to the energetic cost of urea production (Lean \& Westwood, 1997), the requirement for the second N atom from aspartate may exceed aspartate availability, and stimulate aspartate synthesis by the transamination of other amino acids. Lean \& Westwood (1997) speculate that increased hepatic uptake of amino acids to support high levels of urea synthesis may result in a critical shortage of amino acids for milk protein synthesis. This hypothesis warrants experimental study.

\section{Protein turnover}

Recognition of the dynamic state of body proteins stemmed from the experiments of Schoenheimer et al. (1939) using ${ }^{15} \mathrm{~N}$-labelled dietary proteins, as outlined by Munro (1964). Extensive research on protein synthesis and degradation in the 1960s revealed the relatively high energy cost of protein turnover. The significance of this energy cost in relation to the efficiency of protein accretion in livestock was recognized by Blaxter (1967). In the succeeding decade data accumulated on protein turnover in mammalian systems (Waterlow et al. 1978).

Estimates of the energy cost of protein turnover were based initially on the utilization of ATP and GTP in the amino acid acylation of tRNA and the formation of peptide bonds (Waterlow et al. 1978). V. R. Young in his recent scholarly account of amino acid and protein metabolism (Young, 1996) has reviewed evidence that the number of moles of GTP and ATP involved in peptide bond formation and amino acid transport are larger than earlier estimates. Other related issues which impinge on the energy cost of protein turnover include current uncertainty concerning the energy cost of protein degradation, and the involvement of ion pumps, particularly the $\mathrm{Na}^{+}, \mathrm{K}^{+}$-ATPase complex in protein turnover (Young, 1996). The major function of this ion pump is to provide energy for a number of cellular processes which include the movement of amino acids into cells against concentration gradients (Skou, 1991). At this time, the extent to which the energetics of ion movement should be assigned as a primary cost for protein turnover cannot be assessed (Young, 1996).

The factors outlined here that may contribute to the energy cost of protein synthesis may well be influenced by the physiological and nutritional status of the animal. This would explain the variability in the energy cost of protein deposition observed in many studies (Reeds, 1991). Lobley (1993) has provided an authoritative review of the measurement of protein synthesis and breakdown in ruminant tissues.

\section{Protein metabolism and stress}

The remarkably perceptive suggestion of $\mathrm{H}$. Selye that the endocrine, immune and central nervous systems interact in response to stress (Selye, 1936a,b), although not seen as relevant to animal production until comparatively recently (see Griffin, 1989), has been fully validated over the past decade (Kelley, 1988; Blalock, 1989; Arkins et al. 1993; Johnson et al. 1997). 
Responses to stress have been shown to involve bidirectional communication between the three systems mediated by neurotransmitters, hormones, cytokines and receptors (Husband, 1995). The increase in endocrine-immune output in response to stress results in the release of hormones (particularly those of the pituitary-adrenal axis) and cytokines and a change in the socalled 'endocrine-immune gradient' (Elsasser, 1993). Metabolic changes following alterations in the gradient represent a homeorhetic response which alters nutrient partitioning away from growth and skeletal muscle accretion to metabolic processes which, during immunological stress, support the immune response and disease resistance. Many cytokines, such as interleukin-1, tumour necrosis factor- $\alpha$ and interleukin-6, act directly on target tissues such as skeletal muscle, adipose tissue, liver and bone and indirectly alter the circulating levels of hormones such as growth hormone, insulin, glucagon and cortisol. In so doing, they orchestrate glucose homeostasis, increase protein oxidation, muscle proteolysis, $\mathrm{N}$ excretion and hepatic anabolism (Klasing, 1988; Johnson et al. 1997). The net result is reduced growth rate and increased fat deposition.

The new understanding of the integration of endocrine and immune responses to stressors suggests opportunities for intervention to improve animal production and welfare by nutritional strategies, or by the manipulation of hormone and/or cytokine responses (Husband \& Bryden, 1996). The development of appropriate stress paradigms will not be easy as duration of stress is often brief and animals may encounter a number of stressors concurrently. Moreover, the task is made more difficult by the change in voluntary food intake which is the initial response to stress. Despite many years of research (see Forbes, 1995) our understanding of food intake control is incomplete. Since the acquisition and assimilation of nutrients is critical to survival, it is not surprising that this well regulated process is complex and subject to multiple levels of control.

\section{Feeding systems}

Great progress has been made in recent decades in elucidating the biochemical pathways and physiological processes involved in the utilization of dietary $\mathrm{N}$ sources in ruminants. This increased understanding has stimulated efforts to devise computer-based models ranging from theoretical models of physiological processes to mechanistic models of livestock feeding systems. These developments have been discussed at length in the recently published treatise by R. L. Baldwin, the acknowledged leader in this demanding field of research (Baldwin, 1995).

The evolution of systems for estimating the protein requirements of ruminants has been outlined by Oldham (1993). Most of the so-called metabolizable protein systems developed in many countries did not involve the calculation of amino acid requirements (Oldham, 1993). More recently developed systems such as the UK metabolizable protein system (Webster, 1992) and the Cornell net carbohydrate and protein system (see Russell et al. 1992; Chalupa \& Sniffen, 1994) attempt to relate amino acid supply to amino acid requirements.

The intrinsic problems which afflict attempts to predict amino acid supply from the level of feeding and composition of the diet are well recognized (Webster, 1992). The major difficulties concern the estimation of the extent of ruminal degradation of dietary protein and the variability in the efficiency of microbial-protein synthesis in the rumen (see Owens \& Goetsch, 1986; Preston \& Leng, 1987). The latter authors discuss the influence of microbial protein yield on the relative amounts of protein and energy which become available to the animal, and which are the major determinants of the overall efficiency of livestock production. The factors which 
influence the efficiency of microbial production, which include supply of precursors and digesta passage rate have been outlined by Owens \& Goetsch (1986): additional contributors to variability include the protozoal predation of bacteria and bacteriophage activity.

\section{Lipid metabolism}

Lipid metabolism in the rumen and in the major ruminant tissues was comprehensively reviewed in the treatise edited by Christie (1981). At that time it was known that adipose tissue is the only important site of fatty acid synthesis in the non-lactating animal (Vernon, 1981), and that acetate, and not glucose, is the major precursor of long-chain fatty acids (see Annison, 1984).

\section{Growth and deposition of adipose tissue}

White adipose tissue is widely distributed throughout the body. Cellular hyperplasia and hypertrophy are involved at all stages of adipose tissue growth, and both processes can be influenced by nutritional manipulation (Cryer et al. 1992). van der Walt (1984) reported that various adipose tissue depots differ in metabolic activity. The synthesis of long-chain fatty acids, for example, is 2-7-fold higher in backfat than in mesenteric fat, and relative metabolic activities of different adipose tissues may change with age, plane of nutrition and nutritional status. The responsiveness of adipose tissue to insulin and other hormones was fully discussed by Vernon \& Sasaki (1991) and more recently by Vernon (1998) with particular reference to the marked adaptations that occur in pregnancy and lactation.

In normally growing animals, skeletal growth and protein accretion are accompanied by fat accretion. Beyond a certain body weight, which is genotype dependent, fat gain becomes a large and constant fraction of weight gain, and protein accretion becomes almost negligible (Searle et al. 1972; Bergen \& Merkel, 1991).

\section{Nutritional manipulation of carcass fat}

This topic has been reviewed by Ball et al. (1997), who have concluded that efforts to reduce fatness by restricting feed supply, and hence growth rate, have had mixed success. In a number of studies dietary energy restriction reduced fat deposition, but rates of protein gain were maintained (see Ball et al. 1997). The proportional decrease in fat accretion due to feed restriction diminished as animals approached mature size. In contrast, in some studies plane of nutrition had no effect on the body composition of growing animals, and in others feed restriction increased carcass fatness (see Ball et al. 1997). It is likely that these differences in response were influenced by the failure, in some instances, to ensure that the dietary supply of essential amino acids was never rate limiting for protein accretion (Black, 1974). Another important factor in these studies was the stage of maturity at which feed energy was restricted (Carstens et al. 1991). Ball et al. (1997) have suggested that feed restriction at later stages of maturity is more effective in reducing carcass fat than when applied at an early stage of maturity. The interaction of this management practice with genotype would be of interest, however, in view of the convincing evidence of Bergen \& Merkel (1991) that the most successful strategy for reducing carcass fatness has been the breeding and selection of large, late-maturing animals. 


\section{Hormonal manipulation of carcass fat}

The administration of androgenic or oestrogenic steroids to promote protein deposition in ruminants has been widely practised for several decades (see Bell et al. 1998). Both classes of anabolic steroids reduce carcass fatness by partitioning nutrients in favour of muscle production. The mechanism of action of these compounds has not been fully elucidated, but it is known that anabolic steroids increase growth hormone secretion, the numbers of growth hormone receptors in the liver and insulin-like growth factor-1 production (see Meyer et al. 1995). In addition, anabolic steroids almost certainly act directly on muscle tissue, since androgen and oestrogen receptors have been identified in the skeletal muscle of a number of species (see Meyer et al. 1995).

The mode of action of trenbolone acetate, a synthetic androgenic agent which increases protein accretion in sheep and cattle by reducing protein turnover (Buttery \& Sinnett-Smith, 1984), is partly accounted for by inhibitory effects on glucocorticoids. Sharpe et al. (1986) reported that circulating cortisol levels fall and that the numbers of cytosolic receptors for cortisol in muscle are reduced in trenbolone acetate-treated sheep.

A number of synthetic $\beta$-adrenergic agonists, given orally, increase protein accretion and reduce fat deposition (see Bell et al. 1998). The activation of $\beta$-adrenergic receptors stimulates glycogenolysis in muscles and lipolysis in adipose tissue, and by enhancing protein synthesis and reducing tissue protein degradation, increases protein accretion (see Meyer et al. 1995). The major effects of $\beta$-agonists on adipose tissue production are accounted for by increased lipolysis, reduced lipogenesis and reduced triacylglycerol synthesis (Yang \& McElligott, 1989). Indirect effects of $\beta$-agonists which contribute to reduced carcass fatness include the diversion of energy to support both increased protein synthesis, and a higher metabolic rate (see Meyer et al. 1995). Bergen \& Merkel (1991) have reported that the administration of $\beta$-agonists to cattle and pigs reduces fat deposition by approximately $20 \%$.

At this time synthetic $\beta$-adrenergic agonists have not been approved for use in livestock production in USA, Europe or Australasia. The major drawback to their use is that, unlike for example growth hormone, they are orally active, and pose a potential hazard to operatives involved in the preparation and dispensing of animal feeds, and to consumers from possible residues in food (Buttery \& Dawson, 1990).

The vast interest in the production and usage of bovine growth hormone, termed bovine somatotropin, arose from the substantial increases in milk yield achieved when the hormone was administered to lactating cows, as discussed by D. E. Bauman and his colleagues (Bauman \& McCutcheon, 1986; Bauman, 1992) and D. Schams (Schams, 1995). Somatotropin administration to beef cattle increases $\mathrm{N}$ retention, lean tissue growth and efficiency of feed conversion (Buttery \& Dawson, 1990; Bergen \& Merkel, 1991). These effects contribute to the production of leaner carcasses, since animals reach slaughter-weight at an earlier age, when fat deposition is less dominant. Direct effects of bovine somatotropin on adipose tissue include decreases in the activities of lipogenic enzymes, reduced glucose uptake and oxidation, decreased insulin sensitivity and increased lipolysis (see Bergen \& Merkel, 1991) which are largely mediated by the anabolic peptide insulin-like growth factor-1 (Breier \& Sauerwein, 1995).

An alternative approach to the direct administration of bovine somatotropin is to enhance the effects of endogenous growth hormone by immunological intervention. The antibodymediated potentiation of bovine somatotropin activity was first demonstrated by Aston et al. (1987), as discussed by Pell \& Flint (1997) when reviewing the immunomodulation of lactation. Attempts to increase growth hormone release by blocking the activity of somatostatin by 
immunization were successful in a non-improved breed of sheep, but little success has been achieved with commercial breeds (see Flint, 1992). A matter of crucial importance in the use of all growth promotants is plane of nutrition. The supply of energy, essential amino acids, minerals and micronutrients must be adequate to allow tissues to express their capacity for increased growth.

\section{Immunological control of fat deposition}

Efforts to decrease fat deposition by producing antibodies capable of destroying adipocytes were outstandingly successful in rats, which showed reduced body fat, increased appetite and higher growth rates, and a $15 \%$ improvement in feed conversion efficiency (Flint, 1996). Similar approaches have been less successful in meat-producing animals (Flint, 1996) but increased understanding of adipose tissue differentiation and development (see Pond, 1996) may reveal structures or processes more susceptible to immunological manipulation.

\section{Mobilization of adipose tissue}

Although adipose tissue had long been recognized as the major storage form of energy in mammals, it was only in 1956 that Dole (1956) and Gordon \& Cherkes (1956) showed that long-chain fatty acids are mobilized as NEFA, which bind to blood albumin. The low concentrations of plasma NEFA reflect the high turnover of this major intermediate in adipose tissue mobilization and utilization (see Annison, 1964). Progress in knowledge of NEFA metabolism in response to changes in physiological state and plane of nutrition has been charted in reviews by Lindsay (1975), Emery (1979), Annison (1984) and Pethick \& Dunshea (1993). The latter authors have focused attention on the quantitative aspects of NEFA metabolism. Isotope dilution studies have provided much quantitative data, and have confirmed that in adipose tissue lipolysis and fatty acid esterification proceed continuously. The balance of the two processes is determined by energy status and by short- and long-term hormonal control (Vernon, 1981; Pethick \& Dunshea, 1993).

Vernon (1998) has discussed at length the homeorhetic adaptations of adipose tissue to lactation. The mobilization of adipose tissue in response to inadequate energy supply is effected by changes in the balance of insulin and glucagon, catecholamines, adenosine and prostaglandin $\mathrm{E}$ isoforms, which contribute to the signal transduction cascade regulating lipolysis (Vernon, 1998).

\section{Mammary gland metabolism}

The influence of the late James Linzell on current knowledge of all aspects of mammary gland metabolism and milk secretion was profound. His research at Babraham, Cambs., UK, from the mid 1950s until tragically cut short by his death in 1974, provided the basis of much of our current understanding of both mammary gland metabolism and the control of milk secretion. In particular, J. L. Linzell and his colleagues refined the application of the AV difference procedure to the mammary glands of the lactating goat (Linzell, 1974). The AV difference procedure, when combined with isotope dilution based on ${ }^{14} \mathrm{C}$-labelled metabolites yielded quantitative data on the contribution of the major energy yielding nutrients to oxidative metabolism in the mammary gland and, simultaneously, in the whole animal (Linzell, 1974; Linzell \& Annison, 1975; Annison, 1983). The same AV difference procedures were used to 
generate quantitative data on the uptake of amino acids by the lactating goat mammary gland (Mepham \& Linzell, 1966; Mepham, 1971). These studies on milk biosynthesis were made on lactating goats which had been reared, and treated like pets, by James Linzell. Discomfort caused by the catheterization of blood vessels involved in AV difference studies was minimized, and animals showing any ill-health, loss of appetite or reduced milk yields were rigidly excluded from the studies. The significance of the use of essentially unstressed animals in metabolic studies has become apparent with the recognition of the adverse effects of a range of stressors on livestock performance (Husband \& Bryden, 1996).

\section{Current arterio-venous difference procedures}

The precision of AV difference measurements is closely related to the accuracy of blood flow measurements (see Fleet \& Mepham, 1983). A major advance in this area has been the development of the ultrasonic procedures (Transonics Systems Inc., Ithaca, NY, USA) for the continuous monitoring of blood flow. If blood metabolite levels are measured at frequent intervals, accurate $24 \mathrm{~h}$ integrated estimates of metabolite uptake or release can be calculated.

The placement of the blood-flow probe involves major surgery, but the animal usually recovers without incident, and feed intakes return to the pre-operation level within $5-7 \mathrm{~d}$ (Rajczyk et al. 1995). The availability of fibre-optic techniques for the continuous measurement of blood $\mathrm{O}_{2}$ concentrations (Abotts Laboratories Inc., North Chicago, IL, USA) has made possible the continuous measurement of energy expenditure. These extra data can be obtained whenever AV difference measurements are made.

The necessity in AV difference studies of sampling representative venous drainage has long been recognized (Zierler, 1961). A potential difficulty when studying ruminant mammary glands is contamination with blood from the external pudic veins and minor contributions from the perineal veins (Linzell, 1960; Mepham, 1993). This problem has been addressed by Bequette et al. (1998), who have concluded that the most effective solution is to ligate the external pudic veins and perineal arteries and veins.

Two other factors that must be considered in AV difference studies are posture and feeding pattern, both of which influence mammary blood flow and possibly nutrient uptake. Rajczyk et al. (1995) monitored mammary blood flow in cows when standing and lying down, and observed that blood flow increased by $18 \%$ in recumbent animals. In studies with goats fed and milked at different times, the feeding of concentrates twice daily resulted in increased mammary blood flow, a response not seen when the concentrate portion of the ration was fed at intervals of $2 \mathrm{~h}$ (Bequette et al. 1998). As pointed out by Bequette et al. (1998), these temporal blood flow responses are similar to the changes in circulating hormones in dairy cows fed at similar intervals (Sutton et al. 1988).

\section{Glucose metabolism}

Recognition of the role of glucose as a precursor of lactose began in the 19th century, but it was not until 1952 that Reithel et al. (1952) used $\left[{ }^{14} \mathrm{C}\right]$ glucose to demonstrate synthesis of lactose in mammary gland homogenates, as discussed by T. B. Mepham in his scholarly and comprehensive account of the role of glucose in regulating milk secretion (Mepham, 1993). Subsequent studies by S. J. Folley and his colleagues on the relative importance of glucose and acetate in lipogenesis in mammary gland slices were discussed earlier.

The vital role of glucose in mammary gland metabolism was conclusively demonstrated in experiments with the isolated, perfused mammary gland of the lactating goat (Hardwick et al. 1961). Milk secretion ceased without glucose, and was restored when glucose was added to the 
perfusion fluid. The dependence of mammary secretion on glucose supply is almost certainly due to the role of glucose as a precursor of lactose, which after secretion draws water osmotically from the secretory cell (Linzell \& Peaker, 1971a; Mepham, 1993). Application of the AV difference procedure demonstrated the uptake of considerable amounts of glucose by the lactating mammary gland in goats (Linzell, 1974). In fact, twice as much glucose as that required for lactose production was taken up, raising the question of the metabolic fate of absorbed glucose in excess of lactose requirements, as discussed by Mepham (1993). In AV difference studies combined with isotope dilution in goats (Annison \& Linzell, 1964) and cows (Bickerstaffe et al. 1974) estimates were made of the amounts of glucose and acetate entering the circulation which were taken up by the mammary glands, the extent to which glucose uptake contributed to the synthesis of lactose and milk fat glycerol and the contribution of both substrates to $\mathrm{CO}_{2}$ production in the whole animal and in the mammary glands. In both studies, the mammary uptake of glucose was almost exactly balanced stoichiometrically by the output of lactose, and the contributions of glucose to milk fat glycerol and mammary $\mathrm{CO}_{2}$ output (see Mepham, 1993).

The supply of glucose to the mammary gland is directly related both to mammary blood flow and arterial glucose concentration. There is a positive correlation between blood flow and milk yield (Linzell, 1974), but subsequent studies have shown that the intracellular glucose concentration, at least in rats, is the more important determinant in lactose synthesis (Wilde \& Kuhn, 1981). Specific glucose transporters have been identified in rat (Threadgold et al. 1982) and mouse mammary cell membranes (Prosser, 1988), suggesting that glucose transport is the rate limiting step in overall glucose metabolism, as discussed by Mepham (1993).

\section{Acetate metabolism}

McClymont (1951) first demonstrated in AV difference studies that considerable amounts of acetate are taken up by the bovine mammary gland. At much the same time, Folley and his colleagues began a series of studies that demonstrated that acetate is readily utilized by mammary tissue slices. The incorporation of $\left[{ }^{14} \mathrm{C}\right]$ acetate into milk fatty acids was confirmed by Popjak et al. $(1951 a, b)$. In studies based on the isolated perfused goat mammary gland, Linzell and his colleagues (Hardwick et al. 1961; Linzell et al. 1972) confirmed the utilization of acetate, and showed that acetate is not indispensable for lactation. The omission of acetate from the perfusion fluid led to the production of milk of declining fat content, but milk production was unaffected.

AV difference studies combined with isotope dilution techniques were used to measure the uptake and oxidation of acetate by the lactating mammary glands of goats (Annison \& Linzell, 1964), cows (Bickerstaffe et al. 1974) and ewes (King et al. 1985). Acetate uptake was related to arterial concentration, and there were only minor differences in the mammary metabolism of acetate in the three species studied (see Annison, 1984). Endogenous acetate was released by the mammary glands of all three species, as revealed by the decline in specific radioactivity of acetate across the glands during the intravenous infusion of ${ }^{14} \mathrm{C}$-labelled acetate.

\section{Lipid metabolism}

Consumer demand for dairy products fell in the 1960s and 1970s when epidemiological studies revealed an apparent association between saturated fat consumption and cardiovascular disease across many countries. The overwhelming difficulties associated with the interpretation of data generated in population studies has been lucidly discussed by Scott (1997), who has empha- 
sized the need to consider the problem of individual response variation. In spite of the lack of convincing population data on the adverse effects of dietary saturated fats, however, experimental data on the capacity of saturated fats to increase the concentration of atherogenic lipoproteins in blood plasma (see Spady et al. 1993) has led to the adoption in many countries of dietary guidelines which recommend that saturated fats should not make up more than $10 \%$ of total dietary energy (see Havel, 1997).

The concentration and fatty acid composition of milk fat varies widely between species (Davies et al. 1983). Differences in the chain-lengths and degree of unsaturation of fatty acids differentiate the milk fat of many species (Dils, 1983). Ruminant milk fat is characterized by the presence of short- and medium-chain fatty acids which are synthesized de novo within the gland (Dils, 1983). These fatty acids, whose synthesis in animal tissues is confined to the mammary gland, undergo no further chain elongation or desaturation. The longer chain fatty acids in milk fat are derived from blood lipids, and stearic acid undergoes extensive desaturation in the mammary gland.

Early studies of the origin of milk fat were based on changes in the concentration of blood across the gland, but the use of jugular blood instead of arterial blood led to the erroneous conclusion that phospholipids are the main precursors of milk fat (see Moore \& Christie, 1979). By the 1930s, however, it was generally agreed that the only class of blood lipids that could contribute to milk fat synthesis was the fraction that we now know consists mainly of triacylglycerols (Moore \& Christie, 1979). Milk fat was subsequently shown to contain short- and medium-chain fatty acids not present in blood (see Hilditch, 1941), and which therefore must be formed within the mammary gland. The precursors of these fatty acids remained in doubt until Popjak $(1951 a, b)$ showed that acetate is the precursor of all of the short- and mediumchain fatty acids $\left(\mathrm{C}_{4}-\mathrm{C}_{18}\right)$, and for about half of the palmitic acid in milk fat.

A comprehensive study of the uptake and utilization of plasma lipids and acetate by the mammary gland of the fed lactating goat was undertaken by combining AV difference measurements with the continuous infusion of ${ }^{14} \mathrm{C}$-labelled palmitic, oleic or stearic acids, or $\left[{ }^{14} \mathrm{C}\right]$ acetate (Annison et al. 1967b). Uptakes and rates of oxidation of acetate were similar to those found earlier, and the specific radioactivities of the milk fatty acids following the infusion of $\left[{ }^{14} \mathrm{C}\right]$ acetate confirmed the earlier observations of Popjak et al. $(1951 a, b)$. There was no evidence of the incorporation of $\left[{ }^{14} \mathrm{C}\right]$ acetate into stearic or oleic acids. Circulating phospholipids, sterols and sterol esters were found to make no contribution to milk biosynthesis, but there were large AV differences of circulating triacylglycerols, which later studies showed were derived almost entirely from the chylomicron and LDL fractions of circulating lipid (West $e$ a al. 1972). Data from these studies were consistent with earlier views that triacylglycerols are completely hydrolysed during uptake by the mammary gland, and that the fatty acids released during this process equilibrate with plasma free fatty acids. The extensive conversion of stearic acid into oleic acid, first reported in the perfused cow mammary gland by Lauryssens $e t$ al. (1960) was convincingly demonstrated (Annison et al. 1967b).

Fatty acids are synthesized from acetate in the mammary gland largely by pathways which operate in other lipogenic tissues (Dils, 1983). The special feature of the mammary gland is its capacity to release fatty acids of shorter chain length than palmitic acid, the end product of the pathway in other tissues.

Free fatty acids, derived either from blood lipoproteins and chylomicrons or synthesized de novo from acetate are immediately esterified to CoA. The resulting acyl-CoA is the donor form for further glyceride reactions, as outlined in the recent review of German et al. (1997). As pointed out by these authors, desaturase activity in the gland is poorly defined, in spite of its potential impact on the nutritional and physical properties of milk fat. 
In the synthesis of milk triacylglycerols, some fatty acid specificity for the three positions on the glycerol molecule must apply since, for example, higher proportions of the fatty acids on the $s n-3$ position are SCFA, and on $s n-2$, long-chain saturated acids. At this time, however, the precise molecular basis of fatty acid specificity remains unknown (German et al. 1997). This is an area of great interest, in view of the potential advantages of milk triacylglycerols structured for their nutritional or physical properties.

\section{Amino acid metabolism}

Studies in the 1920s and 1930s concluded that amino acid N uptake by the mammary gland was sufficient to account for milk protein synthesis, but much of this early work was hampered by unreliable methods for the measurement of both blood flow and AV differences (see Mepham, 1971; Linzell, 1974). The role of circulating amino acids in milk protein synthesis remained controversial until the use of isotopically-labelled amino acids in precursor- product studies with goats (Barry, 1952) and rabbits (Campbell \& Work, 1952) showed that circulating amino acids are the precursors of casein. Somewhat more than a decade later Mepham \& Linzell (1966) showed that in goats the essential amino acids in milk protein are derived from blood. The absorption of amino acid $\mathrm{N}$ was adequate to provide all of the protein synthesized in the mammary gland, but there was clear evidence of amino acid interconversions before incorporation into milk proteins (see Mepham, 1971). The AV difference procedure was also used to measure amino acid uptakes in the cow (Bickerstaffe et al. 1974) and ewe (Davis \& Bickerstaffe, 1978). In these species, as in the goat, the extraction rates of essential amino acids were much higher than those of the non-essential amino acids (see Annison, 1983). Another common feature was that the uptake of arginine was 2-4-fold greater than its output. Arginine is converted to proline in mammary tissue, and the output of proline in milk often exceeds its uptake by the mammary gland (see Mepham, 1976).

Increased interest in manipulating milk composition in favour of casein (see Valeur, 1997) has resulted in sustained research efforts to elucidate the regulation of amino acid uptake and metabolism by the mammary gland. Current concepts have been reviewed by Bequette $e t$ al. (1998), who with their colleagues have made major contributions in this field (Bequette $e$ al . 1994; Bequette \& Backwell, 1997).

The report by Clark (1975) that the post-ruminal infusion of casein in goats and cows often significantly increased milk yields encouraged the view that in some dietary situations certain essential amino acids could be rate limiting for milk protein synthesis (see Mepham, 1982). Many investigators have examined responses to the post-ruminal infusion of proteins or amino acids, or the intravenous infusion of amino acids in lactating animals, with varying success (see Bequette et al. 1998). The published data suggest that the supply of amino acids to the mammary gland is rarely rate limiting, but that the uptake of circulating amino acids is the critical factor. Bequette et al. (1998) point out that the capacity of the mammary gland to extract circulating amino acids may be a function of the surface area of the mammary capillary bed, which is consistent with the intriguing concept of Lacasse et al. (1996) that blood flow is regulated locally within mammary tissues, possibly via mechanisms capable of sensing substrate deficiencies. This concept is consistent with the considerable variability of amino acid uptake across the lactating mammary gland (Bequette et al. 1998).

The demonstration by Backwell et al. $(1994,1996)$ that circulating peptides are extracted by the mammary gland and used for milk protein synthesis explains, at least in part, the apparent deficit observed in some studies in which the uptake of free amino acids by the 
mammary gland was compared with their output in milk (see Mepham, 1982). The contribution of peptide-bound amino acids to milk protein increases as lactation progresses (Bequette $e t$ al. 1998). The source of circulating peptides in blood remains unknown. Absorbed peptides, or peptides originating in the PDV appear not to contribute to milk protein synthesis. Bequette et al. (1998) have suggested that the reported presence of peptides in portal blood (see Webb et al. 1992) may reflect inadequate analytical procedures, since in their own studies using an improved analytical technique no evidence was obtained of significant entry of peptides into portal blood. Blood albumin has been suggested as a possible source of circulating peptides taken up by the mammary gland, but peptides derived from the turnover of endogenous sources such as collagen and skeletal muscle cannot be ruled out (Bequette et al. 1998). The same authors have presented convincing evidence, based on isotope dilution measurements, of the compartmentation of amino acid pools in the mammary gland. This finding is consistent with current knowledge of amino acid metabolism in other tissues.

\section{Control of milk secretion}

The growth of the mammary gland in pregnancy and lactation, the maintenance of lactation and the removal of milk from the gland are all subject to endocrine control (Forsyth, 1983). A relatively new discovery, however, is that milk production is also subject to autocrine control exerted by a protein termed feedback inhibitor of lactation (FIL), which is produced by the mammary gland and stored in milk (Peaker \& Wilde, 1996). M. Peaker, in his intriguing and scholarly account of the development of the concept of autocrine control (Peaker, 1995), points out that the critical observation was that hourly milking increased milk production in the goat mammary gland (Linzell \& Peaker, 1971b). Intra-mammary control of milk secretion also occurs in other species, and has been studied in women and sows (Hartmann et al. 1995). The possibility of devising techniques or management systems to increase milk yields in dairy cows by minimizing or eliminating the effects of FIL has been discussed by Wilde et al. (1995). Some success has been achieved by the immunization of lactating cows with FIL to generate a systemic anti-FIL antibody (see Wilde et al. 1995), and this approach is likely to attract more attention. Wilde et al. (1995) stress that immunological manipulation of autocrine control may depend on the storage capacity of the cistern, which increases in size at each lactation. The reasonable assumption that FIL is inactive in cisternal milk, possibly because of the absence of receptors, remains to be established (see Wilde et al. 1995).

There are considerable economic benefits in extending the lactation cycle in high-yielding cows (Knight, 1998). An essential feature of extended lactation, however, is an increase in frequency of milking to thrice-daily to minimize the effects of FIL (Knight, 1998). Frequent milking also has long-term effects on milk secretion mediated through altered sensitivity to systemic hormones, particularly prolactin. These effects assist extended lactation by reducing the normal rate of decline in milk yield. In commercial practice extended lactation is facilitated by the use of bovine somatotropin, which indirectly stimulates mammary secretory cell proliferation and probably reduces apoptosis (Knight, 1998).

\section{Concluding comments}

The elucidation of the genetic code by F. H. C. Crick and J. D. Watson in the 1950s has resulted in a sustained high level of research in genetic engineering. Great success has been achieved in the modification of bacteria and plants, but only limited progress has been made in the creation 
of genetically superior livestock. There is little doubt, however, that current technical problems will be overcome. The need for continued research in animal physiology and biochemistry must be emphasized, however, since genetic modification will be more successful if the biological processes involved in key aspects of animal production have been more closely defined. This is particularly valid where attempts are made to modify metabolic pathways, as exemplified by attempts to introduce genetic material into sheep to provide a new pathway for the synthesis of cysteine, which in many dietary situations is rate-limiting for wool growth (see Ward \& Nancarrow, 1995). Furthermore, the full impact on the animal of heritable metabolic or physiological changes must be assessed by quantitative biochemical, physiological and nutritional approaches before their acceptance by the livestock industries.

The ultimate goal of livestock nutritionists is the development of feeding systems which maximize the profitability of production without compromising animal welfare, or the environment. The AUSPIG computer simulation model developed by J. L. Black for the pig industry (Black et al. 1993) exemplifies this approach. The nutrition component of this model, however, is inevitably much simpler than would be the case for a comparable model for ruminants. As discussed earlier, at this time we cannot predict with acceptable precision the supply of amino acids to the small intestine in ruminants. The economic importance of feeding systems for ruminants, however, will continue to drive research to overcome this seemingly intractable problem.

As we move into the next century the objectives of ruminant metabolism and nutrition remain unchanged, although classical approaches to research in these areas are in danger of being overwhelmed by the new biological sciences, molecular biology and transgenics. The social and political environments have seen great changes in recent decades, however, with increased awareness of three major issues relevant to the livestock sciences. These are the protection of the environment, animal welfare and the provision of nutritional guidelines to improve human health. It is in the latter area that extreme care is warranted. The comments of the late K. L. Blaxter of the need for caution when interpreting data on human health remain valid (Blaxter, 1991). Current recognition of the problems associated with the interpretation of data generated in population studies (see Scott, 1997) is entirely consistent with the scepticism of Blaxter (1991) of the quality of the science that led to the alleged causal relationship between the intake of saturated fatty acids and coronary heart disease. The acceptance by health authorities that the intakes of saturated fats should be restricted had severe economic consequences for the ruminant livestock industries in the 1970s and 1980s. Future policy on human nutrition must be based on irrefutable experimental data, and any recommendations should be subjected to rigorous discussion by the scientific community before implementation.

\section{References}

Agricultural and Food Research Council Technical Committee on Responses to Nutrients (1990) Report no. 5, Nutritive requirements of ruminant animals: Energy. Nutrition Abstracts and Reviews (Series B) 60, 729-804.

Ahaix D \& Arnal M (1987) Protein synthesis and growth in the gastrointestinal tract of the young pre-ruminant lamb. British Journal of Nutrition 58, 159-169.

Annison EF (1954) Some observations on volatile fatty acids in the sheep's rumen. Biochemical Journal 57, 400-405. Annison EF (1964) Plasma free fatty acids. In Metabolism and Physiological Significance of Lipids, pp. 289-324 [RMC Dawson and DN Rhodes, editors]. London: Wiley.

Annison EF (1983) Metabolite utilization by the ruminant mammary gland. In Biochemistry of Lactation, pp. 399-436

[TB Mepham, editor]. Amsterdam: Elsevier.

Annison EF (1984) The metabolism of neutral and acidic lipids by tissues of the ruminant. In Herbivore Nutrition in the Subtropics and Tropics, pp. 549-570 [FMC Gilchrist and RI Mackie, editors]. Pretoria: The Science Press. 
Annison EF (1991) Measurement of metabolism in whole animals and their tissues - overview. Proceedings of the Nutrition Society of Australia 16, 146-153.

Annison EF \& Armstrong DG (1970) Volatile fatty acid metabolism. In Physiology of Digestion and Metabolism in the Ruminant, pp. 422-437 [AT Phillipson, editor]. Newcastle-upon-Tyne: Oriel Press.

Annison EF, Brown RE, Leng RA, Lindsay DB \& West CE (1967a) Rates of entry and oxidation of acetate, glucose, $\mathrm{D}(-)-\beta$-hydroxybutyrate, palmitate, oleate and stearate, and rates of production and oxidation of propionate and butyrate in fed and starved sheep. Biochemical Journal 104, 135-147.

Annison EF \& Bryden WL (1998) Perspectives in ruminant nutrition and metabolism. I. Metabolism in the rumen. Nutrition Research Reviews 11, $173-198$.

Annison EF, Hill KJ \& Lewis D (1957) Studies on the portal blood of sheep. 2. Absorption of volatile fatty acids from the rumen of the sheep. Biochemical Journal 66, 592-599.

Annison EF \& Leng RA (1991) A history of the use of isotopic tracer technology in ruminant nutrition: lessons for present research. In Isotope and Related Techniques in Animal Production and Health, pp. 3-23. Vienna: International Atomic Energy Agency.

Annison EF \& Lindsay DB (1961) Acetate utilization in sheep. Biochemical Journal 78, 777-785.

Annison EF \& Linzell JL (1964) The oxidation and utilization of glucose and acetate by the mammary gland in relation to their overall metabolism and to milk formation. Journal of Physiology, London 175, 372-385.

Annison EF, Linzell JL, Fazakerley S \& Nichols BN (1967b) The oxidation and utilization of palmitate, stearate, oleate and acetate by the mammary gland of the fed goat in relation to their overall metabolism, and the role of phospholipids and neutral lipids in milk fat synthesis. Biochemical Journal 102, 637-647.

Annison EF \& Pennington RJ (1954) The metabolism of short-chain fatty acids in the sheep. 3. Formic, $n$-valeric and branched-chain acids. Biochemical Journal 57, 685-692.

Annison EF, Scott TW \& Waites GMH (1963) The role of glucose and acetate in the oxidative metabolism of the testis and epidymis of the ram. Biochemical Journal 88, 482.

Annison EF \& White RR (1961) Glucose utilization in sheep. Biochemical Journal 80, 162-169.

Annison EF \& White RR (1962a) Formate metabolism in sheep. Biochemical Journal 84, 552-557.

Annison EF \& White RR (1962b) Further studies on the entry rates of acetate and glucose in sheep, with special reference to endogenous production of acetate. Biochemical Journal 84, 546-552.

Arkins S, Dantzer R \& Kelley KW (1993) Somatolactogens, somatomedins and immunity. Journal of Dairy Science 76, 2437-2450.

Armstrong DG (1965) Carbohydrate metabolism in ruminants and energy supply. In Physiology of Digestion in the Ruminant, pp. 272-288 [RW Dougherty, RS Allen, W Burroughs, NL Jacobson and AD McGilliard, editors]. Washington, DC: Butterworths.

Armstrong DG \& Blaxter KL (1957) The heat increment of steam-volatile fatty acids in fasting sheep. British Journal of Nutrition 11, 247-271.

Armstrong DG, Blaxter KL \& Graham NMcC (1957) The heat increments of mixtures of steam-volatile fatty acids in fasting sheep. British Journal of Nutrition 11, 392-408.

Armstrong DG, Blaxter KL \& Graham NMcC (1961) The heat increment in fasting sheep of acetic acid partially neutralized with sodium hydroxide. British Journal of Nutrition 15, 169-175.

Aston R, Holder AT, Ivanyi J \& Bomford R (1987) Enhancement of bovine growth hormone activity in vivo by monoclonal antibodies. Molecular Immunology 24, 143-150.

Backwell FRC, Bequette BJ, Wilson D, Calder AG, Metcalf JA, Wray-Cahen D, MacRae JC, Beever DE \& Lobley GE (1994) Utilization of dipeptides by the caprine mammary gland for milk protein synthesis. American Journal of Physiology 267, R1-R6.

Backwell FRC, Bequette BJ, Wilson D, Metcalf JA, Franklin MF, Beever DE, Lobley GE \& MacRae JC (1996) Evidence for the utilization of peptides for milk protein synthesis in the lactating cow in vivo. American Journal of Physiology 271, R955-R960.

Baldwin RL (1995) Modelling Ruminant Digestion and Metabolism. London: Chapman \& Hall.

Ball AJ, Oddy VH \& Thompson JM (1997) Nutritional manipulation of body composition and efficiency in ruminants. In Recent Advances in Animal Nutrition in Australia, 1997, pp. 192-208 [JL Corbett, M Choct, JV Nolan and JB Rowe, editors]. Armidale, NSW, Australia: University of New England.

Ballard FJ, Filsell DH \& Jarrett IG (1972) Effects of carbohydrate availability on lipogenesis in sheep. Biochemical Journal 226, 193-200.

Ballard FJ, Hanson RW \& Kronfeld DS (1969) Gluconeogenesis and lipogenesis in tissue from ruminant and nonruminant animals. Federation Proceedings 28, 218-231.

Balmain JH, Folley SJ \& Glascock RF (1954) Relative utilization of glucose and acetate carbon for lipogenesis by mammary gland slices, studied with tritium, ${ }^{13} \mathrm{C}$ and ${ }^{14} \mathrm{C}$. Biochemical Journal 46, 234-239.

Barcroft J, McAnally RA \& Phillipson AT (1944) Absorption of volatile fatty acids from the alimentary tract of sheep and other species. Journal of Experimental Biology 20, 120-129.

Barry JM (1952) The source of lysine, tyrosine and phosphorus for casein synthesis. Journal of Biological Chemistry 195, 795-803.

Bauman DE (1984) Regulation of nutrient partitioning. In Herbivore Nutrition in the Subtropics and Tropics, pp. 505524 [FMC Gilchrist and RI Mackie, editors]. Pretoria, South Africa: The Science Press. 
Bauman DE (1992) Bovine somatotrophin: review of an emerging animal technology. Journal of Dairy Science 75, $3432-3451$.

Bauman DE \& McCutcheon SN (1986) The effects of growth hormone and prolactin on metabolism. In Control of Digestion and Metabolism in Ruminants, pp. 436-458 [LP Milligan, WL Grovum and A Dobson, editors]. Englewood Cliffs, NJ: Prentice-Hall.

Bell AW, Bauman DE, Beermann DH \& Harrell RJ (1998) Nutrition, development and efficacy of growth modifiers in livestock species. Journal of Nutrition 128, 360S-363S.

Bequette BJ \& Backwell FRC (1997) Amino acid supply and metabolism by the ruminant mammary gland. Proceedings of the Nutrition Society 56, 593-605.

Bequette BJ, Backwell FRC \& Crompton LA (1998) Current concepts of amino acid and protein metabolism in the mammary gland of the lactating ruminant. Journal of Dairy Science (In the Press).

Bequette BJ, Backwell FRC, Dhanoa MS, Walker A, Calder AG, Wray-Cahen D, Metcalf JA, Sutton JD, Beever DE, Lobley GE \& MacRae JC (1994) Kinetics of blood free and milk casein amino acid labelling in the dairy goat at two stages of lactation. British Journal of Nutrition 72, 211-220.

Bergen WG \& Merkel RA (1991) Body composition of animals treated with partitioning agents: implications for human health. FASEB Journal 5, 2951-2957.

Bergman EN (1973) Glucose metabolism in ruminants. Cornell Veterinarian 63, 341-382.

Bergman EN (1975) Production and utilization of metabolites by the alimentary tract as measured in portal and hepatic blood. In Digestion and Metabolism in the Ruminant, pp. 292-305 [IW McDonald and ACI Warner, editors]. Armidale, NSW, Australia: University of New England Publishing Unit.

Bergman EN (1990) Energy contributions of volatile fatty acids from the gastrointestinal tract in various species. Physiological Reviews 70, 567-590.

Bergman EN \& Wolff JE (1971) Metabolism of volatile fatty acids by liver and portal drained viscera of sheep. American Journal of Physiology 221, 586-592.

Bickerstaffe R, Annison EF \& Linzell JL (1974) The metabolism of glucose, acetate, lipids and amino acids in lactating cows. Journal of Agricultural Science, Cambridge 82, 71-85.

Black JL (1974) Manipulation of body composition through nutrition. Proceedings of the Australian Society of Animal Production 10, 211-218.

Black JL, Davies GT \& Fleming JF (1993) Role of computer simulation in the application of knowledge to the animal industries. Australian Journal of Agricultural Research 44, 541-551.

Black JL, Gill M, Beever DE, Thornley JM \& Oldham JD (1987) Simulation of the metabolism of absorbed energyyielding nutrients in young sheep: efficiency of utilization of acetate. Journal of Nutrition 117, 105-115.

Blalock JE (1989) A molecular basis for bidirectional communication between the immune and neuroendocrine systems. Physiological Reviews 69, 1-32.

Blaxter KL (1962) The Energy Metabolism of Ruminants. London: Hutchinson.

Blaxter KL (1967) The Energy Metabolism of Ruminants, 2nd impression, pp. 267-279. London: Hutchinson.

Blaxter KL (1989) Energy Metabolism in Animals and Man. Cambridge: Cambridge University Press.

Blaxter KL (1991) Animal production and food: real problems and paranoia. Animal Production 53, 261-269.

Breier BH \& Sauerwein H (1995) Regulation of growth in ruminants by the somatotrophic axis. In Ruminant Physiology: Digestion, Metabolism, Growth and Reproduction, pp. 451-467 [WV Engelhardt, S Leonhard-Marek, G Breves and D Giesecke, editors]. Stuttgart, Germany: Ferdinand Enke Verlag.

Bryant MP \& Robinson IM (1962) Some nutritional characteristics of predominant culturable ruminal bacteria. Journal of Bacteriology 84, 605-611.

Buttery PJ \& Dawson JM (1990) Growth promotion in farm animals. Proceedings of the Nutrition Society 49, 459-466.

Buttery PJ \& Sinnett-Smith PA (1984) The mode of action of anabolic agents with special reference to their effects on protein metabolism - some speculations. In Manipulation of Growth of Farm Animals, pp. 211-219 [JF Roche and D O'Callaghan, editors]. Boston, MA: Martinus Nijhoff.

Campbell PN \& Work TS (1952) The biosynthesis of proteins. I. Uptake of glycine, serine, valine and lysine by the mammary gland of the rabbit. Biochemical Journal 52, 217-227.

Carstens GE, Johnson DE, Ellenberger MA \& Tatum JD (1991) Physical and chemical components of the empty body during compensatory growth in beef steers. Journal of Animal Science 69, 3251-3264.

Chalupa W \& Sniffen CJ (1994) Carbohydrate, protein and amino acid nutrition of dairy cows. In Recent Advances in Animal Nutrition, pp. 265-275 [PC Garnsworthy and DJA Cole, editors]. Nottingham: Nottingham University Press.

Christie WW (Editor) (1981) Lipid Metabolism in Ruminant Animals. Oxford: Pergamon Press.

Clark JH (1975) Lactation responses to postruminal administration of proteins and amino acids. Journal of Dairy Science 58, 1178-1197.

Corbett JL, Farrell DJ, Leng RA, McClymont GL \& Young BA (1971) Determination of energy expenditure of penned and grazing sheep from estimates of $\mathrm{CO}_{2}$ entry rate. British Journal of Nutrition 26, 277-291.

Costa ND, McIntosh GH \& Snoswell AM (1976) Production of endogenous acetate by the liver in lactating ewes. Australian Journal of Biological Sciences 29, 33-42.

Cryer A, Williams SE \& Cryer J (1992) Dietary and other factors involved in the proliferation, determination and differentiation of adipocyte precursor cells. Proceedings of the Nutrition Society 51, 379-385.

Danfaer A (1994) Nutrient metabolism and utilization in the liver. Livestock Production Science 39, $115-117$. 
Davies DT, Holt C \& Christie WW (1983) The composition of milk. In Biochemistry of Lactation, pp. $71-120$ [TB Mepham, editor]. Amsterdam, The Netherlands: Elsevier.

Davis SR \& Bickerstaffe R (1978) Mammary glucose uptake in the lactating ewe and the use of methionine arteriovenous difference for the calculation of mammary blood flow. Australian Journal of Biological Sciences 31, $133-140$.

Dils RR (1983) Milk fat synthesis. In Biochemistry of Lactation, pp. 141-158 [TB Mepham, editor]. Amsterdam, The Netherlands: Elsevier.

Dole VP (1956) A relation between non-esterified fatty acids in plasma and the metabolism of glucose. Journal of Clinical Investigation 35, 150-154.

Elsasser TH (1993) Endocrine-immune interactions that impact on animal health and productivity. Proceedings of the Maryland Nutrition Conference, pp. 81-88 [DP Thomas, editor]. College Park, MD: University of Maryland.

Elsden SR (1946) The application of the silica gel partition chromatogram to the estimation of volatile fatty acids. Biochemical Journal 40, 252-256.

Elsden SR \& Phillipson AT (1948) Ruminant digestion. Annual Review of Biochemistry 17, 705-726.

Emery RS (1979) Deposition, secretion, transport and oxidation of fat in ruminants. Journal of Animal Science 48, $1530-1537$.

Fleet IR \& Mepham TB (1983) Physiological methods used in the study of mammary substrate utilization in ruminants. In Biochemistry of Lactation, pp. 469-492 [TB Mepham, editor]. Amsterdam, The Netherlands: Elsevier.

Flint DJ (1992) Regulation of fat and lean deposition by the immune system. In The Control of Fat and Lean Deposition, pp. 299-313 [PJ Buttery, KN Boorman and DB Lindsay, editors]. Oxford: Butterworth-Heinemann.

Flint DJ (1996) Immunological manipulation of adiposity. Biochemical Society Transactions 24, 418-422.

Forbes JM (1995) Voluntary Food Intake and Diet Selection in Farm Animals. Wallingford: CAB International.

Forsyth IA (1983) The endocrinology of lactation. In Biochemistry of Lactation, pp. 309-350 [TB Mepham, editor]. Amsterdam, The Netherlands: Elsevier.

German JB, Morand L, Dillard CJ \& Xu R (1997) Milk fat composition: targets for alteration of function and nutrition. In Milk Composition, Production and Biotechnology, pp. 35-72 [RAS Welch, DJW Burns, SR Davis, AI Popay and CG Prosser, editors]. Hamilton, New Zealand: CAB International.

Giles LR, Annison EF, Black JL, Tucker RG \& Gooden JM (1995) A new procedure for the continuous measurement of $\mathrm{O}_{2}$ consumption in pigs. Journal of Agricultural Science, Cambridge 124, 113-118.

Gill M, Thornley JMH, Black JL, Oldham JD \& Beever DE (1984) Simulation of the metabolism of absorbed energyyielding nutrients in young sheep. British Journal of Nutrition 52, 621-649.

Gordon RS \& Cherkes A (1956) Unesterified fatty acid in human blood plasma. Journal of Clinical Investigation 35, $206-212$.

Gray GM (1992) Starch digestion and absorption in non-ruminants. Journal of Nutrition 122, $172-177$.

Griffin JFT (1989) Stress and immunity: a unifying concept. Veterinary Immunology and Immunopathology 20, $263-312$.

Guerino F, Huntingdon GB \& Erdman RA (1991) The net portal and hepatic flux of metabolites and $\mathrm{O}_{2}$ consumption in growing beef steers given postruminal casein. Journal of Animal Science 69, 387-395.

Hardwick DC, Linzell JL \& Price SM (1961) The effect of glucose and acetate on milk secretion in the perfused goat udder. Biochemical Journal 80, 37-45.

Harmon DL (1992) Dietary influences on carbohydrases and small intestinal starch hydrolysis capacity in ruminants. Journal of Nutrition 122, 203-210.

Harmon DL (1993) Nutritional regulation of postruminal digestive enzymes in ruminants. Journal of Dairy Science 76, $2102-2111$.

Harris PM, Waghorn GC \& Lee J (1990) Nutritional partitioning of growth for productive gain. Proceedings of the New Zealand Society of Animal Production 50, 81-90.

Hartmann PE, Atwood CS, Cox DB \& Daly SEJ (1995) Endocrine and autocrine strategies for the control of lacation in women and sows. In Intercellular Signaling in the Mammary Gland, pp. 203-244 [CJ Wilde, M Peaker and CH Knight, editors]. New York, NY: Plenum Press.

Havel RJ (1997) Milk fat consumption and human health: recent NIH and other American Governmental recommendations. In Milk Composition, Production and Biotechnology, pp. 13-22 [RAS Welch, DJW Burns, SR Davis, AI Popay and CG Prosser, editors]. Hamilton, New Zealand: CAB International.

Heald PJ (1952) The assessment of glucose-containing substances in rumen micro-organisms during a digestion cycle in sheep. British Journal of Nutrition 5, 84-93.

Hilditch TP (1941) The Chemical Constituents of Natural Fats. New York, NY: John Wiley.

Hungate RE (1966) The Rumen and its Microbes. New York, NY: Academic Press.

Huntington GB (1989) Hepatic urea synthesis and site and route of urea removal from blood of beef steers fed alfalfa hay or a concentrate diet. Canadian Journal of Animal Science 69, 215-223.

Huntington GB (1997) Starch utilization by ruminants: from basics to the bunk. Journal of Animal Science 75, 852867.

Huntingdon GB \& Reynolds PJ (1986) Net absorption of glucose, L-lactate, volatile fatty acids and nitrogenous compounds by bovine given abomasal infusions of starch or glucose. Journal of Dairy Science 69, 2428-2436.

Husband AJ (1995) The immune system and integrated homeostasis. Immunology and Cell Biology 73, $377-382$. 
Husband AJ \& Bryden WL (1996) Nutrition, stress and immune activation. Proceedings of the Nutrition Society of Australia 20, 60-70.

James AT \& Martin AJP (1952) Gas-liquid partition chromatography: the separation and micro-estimation of volatile fatty acids from formic acid to dodecanoic acid. Biochemical Journal 50, 679-690.

Janes AN, Weekes TEC \& Armstrong DG (1985) Absorption and metabolism of glucose by the mesenteric-drained viscera of sheep fed on dried grass or ground maize based diets. British Journal of Nutrition 54, 449-458.

Johnson RW, Arkins S, Dantzer R \& Kelley KW (1997) Hormones, lymphohemopoietic cytokines and the neuroimmune axis. Comparative Biochemistry and Physiology 116A, 183-201.

Kelley KW (1988) Cross-talk between the immune and endocrine systems. Journal of Animal Science 66, $2095-2108$.

King KR, Gooden JM \& Annison EF (1985) Acetate metabolism in the mammary gland of the lactating ewe. Australian Journal of Biological Sciences 38, 23-31.

Klasing KC (1988) Nutritional aspects of leukocytic cytokines. Journal of Nutrition 118, 1436-1446.

Knight CH (1998) Extended lactation. In Hannah Research Institute Yearbook, pp. 30-39 [E Taylor, editor]. Ayr, Scotland: Hannah Research Institute.

Kristensen NB, Danfaer A, Tetens V \& Agergaard N (1996) Portal recovery of intraruminally infused short-chain fatty acids in sheep. Acta Agriculturae Scandinavica Section A, Animal Science 46, 26-38.

Lacasse P, Farr VC, Davis SR \& Prosser CG (1996) Local secretion of nitric oxide and the control of mammary blood flow. Journal of Dairy Science 79, 1369-1374.

Lauryssens M, Verbeke R, Peeters G \& Reinards MT (1960) Incorporation of $\left[1-{ }^{14} \mathrm{C}\right]$ and $\left[3-{ }^{14} \mathrm{C}\right]$ butyrate into milk constituents by the perfused cow's udder. Journal of Dairy Research 27, 151-160.

Lean IJ \& Westwood CT (1997) Challenges to achieving high production from dairy cows in Australia. In Recent Advances in Animal Nutrition in Australia, 1997, pp. 192-208 [JL Corbett, M Choct, JV Nolan and JB Rowe, editors]. Armidale, NSW, Australia: University of New England.

Leng RA (1990) Factors affecting the utilization of 'poor quality' forages by ruminants, particularly under tropical conditions. Nutrition Research Reviews 3, 277-303.

Lescale-Matys L, Dyer J, Scott D, Freeman TC, Wright EM \& Shirazi-Beechey SP (1993) Regulation of the ovine intestinal $\mathrm{Na}^{+}$-glucose co-transporter (SGLT1) is dissociated from mRNA abundance. Biochemical Journal 291, $435-440$.

Lewis D, Hill KJ \& Annison EF (1957) Studies on the portal blood of sheep. 1. Absorption of $\mathrm{NH}_{3}$ from the rumen of the sheep. Biochemical Journal 66, 587-592.

Lifson N, Gordon GV \& McClintock R (1955) Measurement of total $\mathrm{CO}_{2}$ production by means of $\mathrm{D}_{2} \mathrm{O}^{18}$. Journal of Applied Physiology 7, 704-710.

Lindsay DB (1959) The significance of carbohydrate in ruminant nutrition. Veterinary Reviews Annotations 5, $103-128$.

Lindsay DB (1970) Carbohydrate metabolism in the ruminant. In Physiology of Digestion and Metabolism in the Ruminant, pp. 438-451 [AT Phillipson, editor]. Newcastle-upon-Tyne: Oriel Press.

Lindsay DB (1975) Fatty acids as energy sources. Proceedings of the Nutrition Society 34, 241-248.

Lindsay DB (1978) Gluconeogenesis in ruminants. Biochemical Society Transactions 8, 1152-1156.

Lindsay DB (1993a) Making the sums add up - the importance of quantification in nutrition. Australian Journal of Agricultural Research 44, 479-493.

Lindsay DB (1993b) Metabolism of the portal-drained viscera. In Quantitative Aspects of Ruminant Digestion and Metabolism, pp. 267-289 [JM Forbes and J France, editors]. Cambridge: CAB International.

Linzell JL (1960) Valvular incompetence in the venous drainage of the udder. Journal of Physiology, London 153, 481491.

Linzell JL (1974) Mammary blood flow and methods of identifying and measuring precursors of milk. In Lactation, vol. 1, pp. 143-225 [BL Larson and VR Smith, editors]. New York, NY: Academic Press.

Linzell JL \& Annison EF (1975) Methods of measuring the utilization of metabolites absorbed from the alimentary tract. In Digestion and Metabolism in the Ruminant, pp. 306-319 [IW McDonald and ACI Warner, editors]. Armidale, NSW, Australia: University of New England Publishing Unit.

Linzell JL, Fleet IR, Mepham TB \& Peaker M (1972) Perfusion of the isolated mammary gland of the goat. Quarterly Journal of Experimental Physiology 57, 139-161.

Linzell JL \& Peaker M (1971a) Mechanism of milk secretion. Physiological Reviews 51, 564-597.

Linzell JL \& Peaker M $(1971 b)$ The effects of oxytocin and milk removal on milk secretion in the goat. Journal of Physiology, London 216, 717-734.

Lobley GE (1991) Organ and tissue metabolism: present status and future trends. In Energy Metabolism of Farm Animals. EAAP Publication no. 58. pp. 80-87 [C Wenk and M Boessinger, editors]. Zurich, Switzerland: Institut für Nutztierwissenschaften.

Lobley GE (1993) Protein metabolism and turnover. In Quantitative Aspects of Ruminant Digestion and Metabolism, pp. 313-340 [JM Forbes and J France, editors]. Cambridge: CAB International.

Lobley GE, Connell A, Lomax MA, Brown DS, Milne E, Calder AG \& Farningham DAH (1995) Hepatic detoxification in the ovine liver; possible consequences for amino acid catabolism. British Journal of Nutrition 73, 667-685.

Lomax MA \& Baird GD (1983) Blood flow and nutrient exchange across the liver and gut of the dairy cow. British Journal of Nutrition 49, 481-496. 
McClymont GL (1951) Volatile fatty acid metabolism of ruminants, with special reference to the lactating bovine mammary gland and the composition of milk. Australian Journal of Agricultural Research 2, 158-180.

McLean JA \& Tobin G (1987) Animal and Human Calorimetry. Cambridge: Cambridge University Press.

Maltby SA, Reynolds CK, Lomax MA \& Beever DE (1993) The effect of increased absorption of $\mathrm{NH}_{3}$ and arginine on splanchnic metabolism of beef steers. Animal Production 56, 462.

Masson MJ \& Phillipson AT (1951) The absorption of acetate, propionate and butyrate from the rumen of sheep. Journal of Physiology, London 113, 189-206.

Mepham TB (1971) Amino acid utilisation by the lactating mammary gland. In Lactation, pp. $297-315$ [IR Falconer, editor]. London: Butterworths.

Mepham TB (1993) The development of ideas on the role of glucose in regulating milk secretion. Australian Journal of Agricultural Research 44, 509-522.

Mepham TB \& Linzell JL (1966) A quantitative assessment of the contribution of individual plasma amino acids to the synthesis of milk proteins by the goat mammary gland. Biochemical Journal 101, 76-83.

Meyer HHD, Stoffel B \& Hagen-Mann K (1995) $\beta$-Agonists, anabolic steroids and their receptors: new aspects in growth regulation. In Ruminant Physiology: Digestion, Metabolism, Growth and Reproduction, pp. 475-481 [WV Engelhardt, S Leonhard-Marek, G Breves and D Giesecke, editors]. Stuttgart, Germany: Ferdinand Enke Verlag.

Moore JH \& Christie WW (1979) Lipid metabolism in the mammary gland of ruminant animals. Progress in Lipid Research 17, 347-395.

Munro HN (1964) Introduction. In Mammalian Protein Metabolism, vol. 1 [HN Munro and JB Allison, editors]. New York, NY: Academic Press.

Nehring K, Schiemann R \& Hoffmann L (1969) A new system of energetic evaluation of food on the basis of net energy for fattening. In Energy Metabolism of Farm Animals, pp. 41-50 [KL Blaxter, J Kielanowski and G Thorbek, editors]. Newcastle-upon-Tyne: Oriel Press.

Neutze SA, Gooden JM \& Oddy VH (1996) Uptake of labelled phenylalanine into different blood fractions in the portal vein and cranial mesenteric vein of lambs. Journal of Agricultural Science, Cambridge 126, 511-518.

Oldham JD (1993) Protein requirement systems for ruminants. In Progress in Dairy Science, pp. 3-28 [CJC Phillips, editor]. Hamilton, New Zealand: CAB International.

Ørskov ER (1990) Utilization of the energy of absorbed nutrients. In Energy Nutrition in Ruminants, pp. 84-101 [ER Ørskov, editor]. London: Butterworths.

Ørskov ER \& MacLeod NA (1993) Effect of level of input of different proportions of volatile fatty acids on energy utilization in growing ruminants. British Journal of Nutrition 70, 679-687.

Owens FN \& Goetsch AL (1986) Digesta passage and microbial protein synthesis. In Control of Digestion and Metabolism in Ruminants, pp. 196-223 [LP Milligan, WL Grovum and A Dobson, editors]. Englewood Cliffs, NJ: Prentice-Hall.

Owens FN, Zinn RA \& Kim YK (1986) Limits to starch digestion in the ruminant small intestine. Journal of Animal Science 63, 1634-1648.

Peaker M (1995) Autocrine control of milk secretion: development of the concept. In Intercellular Signaling in the Mammary Gland, pp. 193-202 [CJ Wilde, M Peaker and CH Knight, editors]. New York, NY: Plenum Press.

Peaker M \& Wilde CJ (1996) Feedback control of milk secretion from milk. Journal of Mammary Gland Biology and Neoplasia 1, 307-315.

Pell JM \& Flint DJ (1997) Immunomodulation of lactation. In Milk Composition, Production and Biotechnology, pp. 307-317 [RAS Welch, DJW Burns, SR Davis, AI Popay and CG Prosser, editors]. Hamilton, New Zealand: CAB International.

Pennington RJ (1952) The metabolism of short-chain fatty acids in the sheep. Biochemical Journal 51, 251 - 258.

Pennington RJ (1954) The metabolism of short-chain fatty acids in the sheep. 2. Further studies with rumen epithelium. Biochemical Journal 56, 410-416.

Pennington RJ \& Sutherland TM (1956) The metabolism of short-chain fatty acids in the sheep. 4. The pathway of propionate metabolism in rumen epithelial tissue. Biochemical Journal 63, 618-628.

Pethick DW (1993) Carbohydrate and lipid oxidation during exercise. Australian Journal of Agricultural Research 44, $431-441$.

Pethick DW \& Dunshea FR (1993) Fat metabolism and turnover. In Quantitative Aspects of Ruminant Digestion and Metabolism, pp. 291-312 [JM Forbes and J France, editors]. Cambridge: CAB International.

Pethick DW, Miller CM \& Harman NG (1991) Exercise in Merino sheep - the relationships between work intensity, endurance, anaerobic threshold and glucose metabolism. Australian Journal of Agricultural Research 42, 599-620.

Pond CM (1996) Adipose tissue differentiation and development. Biochemical Society Transactions 24, 393-400.

Popjak G, French TH \& Folley SJ (1951a) Utilization of acetate for milk fat synthesis in the lactating goat. Biochemical Journal 48, 411-416.

Popjak G, French TH, Hunter GD \& Martin SJP (1951b) Mode of formation of milk fatty acids from acetate in the goat. Biochemical Journal 48, 612-618.

Preston TR \& Leng RA (1987) Matching Ruminant Production in the Tropics and Sub-Tropics, p. 49. Armidale, NSW, Australia: Penambul Books.

Prior RL (1978) Effect of level of feed intake on lactate and acetate metabolism and lipogenesis in vivo in sheep. Journal of Nutrition 108, 926-935. 
Prosser CG (1988) Mechanism of the decrease in hexose transport by mouse mammary epithelial cells caused by fasting. Biochemical Journal 249, 149-154.

Rajczyk ZK, Sweeting A, Lean IJ \& Gooden JM (1995) Postural effects on mammary blood flow and nutrient uptake. Proceedings of the Nutrition Society of Australia 19, 119.

Reeds PJ (1991) Growth. In Energy Metabolism of Farm Animals. EAAP Publication no. 58, pp. 206-208 [C Wenk and M Boessinger, editors]. Zurich, Switzerland: Institut für Nutztierwissenschaften.

Reid RL (1950) Studies on the carbohydrate metabolism of sheep. II. The uptake by tissues of glucose and acetic acid from the peripheral circulation. Australian Journal of Agricultural Research 1, 338-354.

Reid RL (1952) Studies on the carbohydrate metabolism of sheep. V. The effect of hyperglycemia and insulin on the rate of extrahepatic glucose assimilation. Australian Journal of Agricultural Research 3, 160-167.

Reithel FJ, Horowitz MG, Davidson HM \& Kittinger GW (1952) Formation of lactose in homogenates of mammary gland. Journal of Biological Chemistry 194, 839-848.

Reynolds CK (1995) Quantitative aspects of liver metabolism in ruminants. In Ruminant Physiology: Digestion, Metabolism, Growth and Reproduction, pp. 351-371 [WV Engelhardt, S Leonhard-Marek, G Breves and D Giesecke, editors]. Stuttgart, Germany: Ferdinand Enke Verlag.

Reynolds CK, Casper DP, Harmon DL \& Milton CT (1992a) Effect of CP and ME intake on visceral nutrient metabolism in beef steers. Journal of Animal Science 70, Suppl. 1, 315.

Reynolds CK, Harmon DL, Prior RL \& Tyrrell HF (1994) Effects of mesenteric vein L-alanine infusion on liver metabolism of organic acids in beef heifers fed diets differing in forage to concentrate ratio. Journal of Animal Science 72, 3196-3206.

Reynolds CK, Huntington GB, Tyrrell HF \& Reynolds PJ (1988) Net portal-drained visceral and hepatic metabolism of glucose, L-lactate and nitrogenous compounds in lactating Holstein cows. Journal of Dairy Science 71, 2395-2405.

Reynolds CK, Lapierre H, Tyrrell HF, Elsasser TH, Staples RC, Gaudreau P \& Brazeau P (1992b) Effect of growth hormone releasing factor and feed intake on energy metabolism in growing beef steers: net nutrient metabolism by portal drained viscera and liver. Journal of Animal Science 70, 752-763.

Rittenberg D \& Bloch K (1945) The utilization of acetic acid for the synthesis of fatty acids. Journal of Biological Chemistry 160, 417-424.

Rocha HJG, Connell A \& Lobley GE (1994) Whole body and trans-organ bicarbonate kinetics in sheep: effects of nutritional status. In Energy Metabolism of Farm Animals. EAAP publication no. 76, pp. 27-30 [JF Aguilera, editor]. Zurich, Switzerland: Institut für Nutztierwissenschaften.

Rowe JB \& Pethick DW (1994) Starch digestion in ruminants - problems, solutions and opportunities. Proceedings of the Nutrition Society of Australia 18, 40-52.

Russell JB, O'Connor JD, Fox DG, Van Soest PJ \& Sniffen CJ (1992) A net carbohydrate and protein system for evaluating cattle diets. II. Carbohydrate and protein availability. Journal of Animal Science 70, 3562-3577.

Schams D (1995) Recent implications of the hormonal control of lactation. In Ruminant Physiology: Digestion, Metabolism, Growth and Reproduction, pp. 429-450 [WV Engelhardt, S Leonhard-Marek, G Breves and D Giesecke, editors]. Stuttgart, Germany: Ferdinand Enke Verlag.

Schiemann R (1969) The scientific demands made of a system for evaluating feeds as energy sources and progress made towards their realization. In Energy Metabolism of Farm Animals, pp. 31-40 [KL Blaxter, J Kielanowski and G Thorbek, editors]. Newcastle-upon-Tyne: Oriel Press.

Schoenheimer R, Ratner S \& Rittenberg D (1939) Studies in protein metabolism. VII. The metabolism of tyrosine. Journal of Biological Chemistry 127, 333-344.

Schoenheimer R \& Rittenberg D (1935) Deuterium as indicator in the study of intermediary metabolism. Science 82 , $158-159$.

Scollan ND (1994) Studying metabolic systems in vivo; the role of nuclear magnetic resonance spectroscopy. In Energy Metabolism in Farm Animals. EAAP Publication no. 76, pp. 41-45 [JF Aguilera, editor]. Zurich, Switzerland: Institut für Nutztierwissenschaften.

Scott PJ (1997) Milk consumption and individual responses. In Milk Composition, Production and Biotechnology, pp. 23-34 [RAS Welch, DJW Burns, SR Davis, AI Popay and CG Prosser, editors]. Hamilton, New Zealand: CAB International.

Seal CJ \& Reynolds CK (1993) Nutritional implications of gastrointestinal and liver metabolism in ruminants. Nutrition Research Reviews 6, 185-208.

Seale JL, Rumpler WV \& Conway JM (1989) Comparison of energy expenditure determined by direct/indirect calorimetry and doubly labelled water in adult men. In Energy Metabolism in Farm Animals. EAAP Publication no. 43, pp. 337-340 [Y van der Honing and WH Close, editors]. Zurich, Switzerland: Institut für Nutztierwissenschaften. Searle TW, Graham NMcC \& O'Callaghan M (1972) Growth in sheep. 1. The chemical composition of the body. Journal of Agricultural Science, Cambridge 79, 371-382.

Selye H (1936a) A syndrome produced by diverse nocuous agents. Nature 138, 32.

Selye H (1936b) Thymus and adrenals in the response of the organism to injuries and intoxication. British Journal of Experimental Pathology 17, 234-248.

Shahneh AZ, Giles LR, Newman R, Rigby RDG, Gooden JM \& Wynn PC (1994) Energy expenditure in exercising sheep immunized against adrenocorticotrophin (ACTH). In Energy Metabolism of Farm Animals. EAAP Publication no. 76, pp. 109-112 [JF Aguilera, editor]. Zurich, Switzerland: Institut für Nutztierwissenschaften. 
Sharpe PM, Buttery PJ \& Haynes NB (1986) The effect of manipulating growth in sheep by diet or anabolic agents on plasma cortisol and muscle glucocorticoid receptors. British Journal of Nutrition 56, 289-304.

Shirazi-Beechey SP, Wood IS, Dyer J, Scott D \& King TP (1995) Intestinal sugar transport in ruminants. In Ruminant Physiology: Digestion, Metabolism, Growth and Reproduction, pp. 117-134 [WV Engelhardt, S Leonhard-Marek, G Breves and D Giesecke, editors]. Stuttgart, Germany: Ferdinand Enke Verlag.

Skou JC (1991) The energy coupled exchange of $\mathrm{Na}^{+}$for $\mathrm{K}^{+}$across the cell membrane. The Na ${ }^{+} \mathrm{K}^{+}$pump. FEBS Letters 268, 314-324.

Spady DK, Woollet LA \& Dietschy JM (1993) Regulation of plasma LDL-cholesterol levels by dietary cholesterol and fatty acids. Annual Review of Nutrition 13, 355-381.

Steinhour WD \& Bauman DE (1988) Propionate metabolism: a new interpretation. In Aspects of Digestive Physiology in Ruminants, pp. 238-256 [A Dobson and MJ Dobson, editors]. Ithaca, NY: Comstock Publishing Associates.

Sutton JD, Hart IC, Moran E, Schuler AD \& Simmonds AD (1988) Feeding frequency for lactating cows: diurnal patterns of hormones and metabolites in peripheral blood in relation to milk-fat concentration. British Journal of Nutrition 60, 265-274.

Tagari H \& Bergman EN (1978) Intestinal disappearance and portal blood appearance of amino acids in sheep. Journal of Nutrition 108, 790-803.

Taniguchi K, Huntington GB \& Glenn BP (1995) Net nutrient flux by visceral tissues of beef steers given abomasal and ruminal infusions of casein and starch. Journal of Animal Science 73, 236-249.

Taniguchi KY, Sunada Y \& Obitsu T (1993) Starch digestion in the small intestine of sheep sustained by intragastric infusion without protein supply. Animal Science and Technology, Japan 64, 892-898.

Threadgold LC, Coore HG \& Kuhn NJ (1982) Monosaccharide transport into lactating rat mammary acini. Biochemical Journal 204, 493-501.

Tyrrell HF, Reynolds PJ \& Moe PW (1979) Effect of diet on partial efficiency of acetate use for body tissue synthesis by mature cattle. Journal of Animal Science 48, 598-606.

Valeur J (1997) Milk protein production and market prospects. In Milk Composition, Production and Biotechnology, pp. 93-140 [RAS Welch, DJW Burns, SR Davis, AI Popay and CG Prosser, editors]. Hamilton, New Zealand: CAB International.

van der Walt JG (1984) Metabolic interactions of lipogenic precursors in the ruminant. In Herbivore Nutrition in the Subtropics and Tropics, pp. 571-596 [FMC Gilchrist and RI Mackie, editors]. Pretoria, South Africa: The Science Press.

van der Walt JG (1993) Nitrogen metabolism of the ruminant liver. Australian Journal of Agricultural Science 44, $381-403$.

van Es AJH (1978) Feed evaluation for ruminants. 1. The systems in use from May 1977 onwards in The Netherlands. Livestock Production Science 5, 331-345.

van Es AJH (1994) The symposia on energy metabolism of farm animals of the EAAP. In Energy Metabolism of Farm Animals, pp. 409-418 [JF Aguilera, editor]. Madrid, Spain: CSIC Publishing Service.

Vermorel M (1978) Feed evaluation for ruminants. II. The new energy systems proposed in France. Livestock Production Science 5, 347-365.

Vernon RG (1981) Lipid metabolism in the adipose tissue of ruminant animals. In Lipid Metabolism in Ruminant Animals, pp. 279-362 [WW Christie, editor]. Oxford: Pergamon Press.

Vernon RG (1998) Homeorhesis. In Hannah Research Institute Yearbook, pp. 64-73 [E Taylor, editor]. Ayr, Scotland: Hannah Research Institute.

Vernon RG \& Sasaki S (1991) Control of responsiveness of tissues to hormones. In Physiological Aspects of Digestion and Metabolism in Ruminants, pp. 155-182 [T Tsuda, Y Sasaki and R Kawashima, editors]. San Diego, CA: Academic Press.

Ward KA \& Nancarrow CD (1995) The commercial and agricultural applications of animal transgenesis. Molecular Biotechnology 4, 167-178.

Ward S \& MacLeod MG (1991) Doubly labelled water measurements of the energy metabolism of an avian species under different ambient temperatures and reproductive states. In Energy Metabolism of Farm Animals. EAAP Publication no. 43, pp. 230-233 [C Wenk and M Boessinger, editors]. Zurich, Switzerland: Institut für Nutztierwissenschaften.

Waterlow JC, Garlick PJ \& Millward DJ (1978) Protein Turnover in Mammalian Tissues and in the Whole Body. Amsterdam, Holland: North Holland Publishing Company.

Webb KE (1990) Intestinal absorption of protein hydrolysis products: a review. Journal of Animal Science 68, 3011-3022.

Webb KE Jr, Matthews JC \& DiRienzo DB (1992) Peptide absorption: a review of current concepts and future perspectives. Journal of Animal Science 70, 3248-3257.

Webster AJF (1989) Energy utilization during growth and reproduction. In Energy Metabolism of Farm Animals. EAAP Publication no. 43, pp. 85-88 [Y van der Honing and WH Close, editors]. Zurich, Switzwerland: Institut für Nutztierwissenschaften.

Webster AJF (1992) The metabolisable protein system for ruminants. In Recent Advances in Animal Nutrition - 1992, pp. 93-110 [PC Garnsworthy, editor]. London: Butterworths.

Weekes TE (1991) Hormonal control of glucose metabolism. In Physiological Aspects of Digestion and Metabolism in Ruminants, pp. 183-200 [T Tsuda, Y Sasaki and R Kawashima, editors]. San Diego, CA: Academic Press. 
West CE, Bickerstaffe R, Annison EF \& Linzell JL (1972) Studies on the mode of uptake of blood triglycerides by the mammary gland of the lactating goat. The uptake and incorporation into milk fat and mammary lymph of labelled glycerol, fatty acids and triglycerides. Biochemical Journal 126, 477-490.

White RG \& Leng RA (1969) Carbon dioxide entry rate as an index of energy expenditure in lambs. Proceedings of the Australian Society of Animal Production 7, 335-341.

Whitelaw FG, Brockway JM \& Reid RS (1972) Measurement of $\mathrm{CO}_{2}$ production in sheep by isotope dilution. Quarterly Journal of Experimental Physiology 57, 37-55.

Wilde CJ, Addey CVP, Boddy-Finch LM \& Peaker M (1995) Autocrine control of milk secretion: from concept to application. In Intercellular Signaling in the Mammary Gland, pp. 227-237 [CJ Wilde, M Peaker and CH Knight, editors]. New York, NY: Plenum Press.

Wilde CJ \& Kuhn NJ (1981) Lactose synthesis and utilization of glucose by rat mammary acini. International Journal of Biochemistry 132, 311-316.

Williams SR \& Gadian DR (1986) Tissue metabolism studied in vivo by nuclear magnetic resonance. Quarterly Journal of Experimental Physiology 71, 335-360.

Wolff JE \& Bergman EN (1972) Gluconeogenesis from plasma amino acids in fed sheep. American Journal of Physiology 223, 455-460.

Yang YT \& McElligott M (1989) Multiple action of $\beta$-adrenergic agonists on skeletal muscle and adipose tissue. Biochemistry 261, 1-10.

Young VR (1996) Protein and amino acid metabolism and nutrition: what have we learned between the 6th and 7th International Symposium. In Protein Metabolism and Nutrition, pp. 3-40 [AF Nunes, AV Portugal, JP Costa and JR Ribeiro, editors]. Santarém, Portugal: Instituto Nacional de Investigacao Agraria.

Zierler KL (1961) Theory of the use of arterio-venous concentration differences for measuring metabolism in steady and non-steady states. Journal of Clinical Investigation 40, 2111-2125.

Zierler KL (1976) Fatty acids as substrates for heart and skeletal muscle. Circulation Research 38, 459-463. 